\title{
Grafting Tomato as a Tool to Improve Salt Tolerance
}

\author{
Hira Singh ${ }^{1}$, Pradeep Kumar ${ }^{2, *}$, Ashwani Kumar ${ }^{3}$, Marios C. Kyriacou ${ }^{4}{ }^{\oplus}$, Giuseppe Colla ${ }^{5}(\mathbb{C}$ \\ and Youssef Rouphael ${ }^{6, *(D)}$ \\ 1 Department of Vegetable Science, Punjab Agricultural University, Ludhiana 141004, India; hira@pau.edu \\ 2 ICAR-Central Arid Zone Research Institute, Jodhpur 342003, India \\ 3 ICAR-Central Soil Salinity Research Institute, Karnal 132001, India; Ashwani.Kumar1@icar.gov.in \\ 4 Department of Vegetable Crops, Agricultural Research Institute, 1516 Nicosia, Cyprus; \\ m.kyriacou@ari.gov.cy \\ 5 Department of Agriculture and Forest Sciences, University of Tuscia, 01100 Viterbo, Italy; giucolla@unitus.it \\ 6 Department of Agricultural Sciences, University of Naples Federico II, 80055 Portici, Italy \\ * Correspondence: pradeephort@gmail.com (P.K.); youssef.rouphael@unina.it (Y.R.)
}

Received: 16 December 2019; Accepted: 11 February 2020; Published: 12 February 2020

\begin{abstract}
Salinity in soil or water is a serious threat to global agriculture; the expected acreage affected by salinity is about $20 \%$ of the global irrigated lands. Improving salt tolerance of plants through breeding is a complex undertaking due to the number of traits involved. Grafting, a surgical mean of joining a scion and rootstock of two different genotypes with the desired traits, offers an alternative to breeding and biotechnological approaches to salt tolerance. Grafting can also be used to circumvent other biotic and abiotic stresses. Increasing salinity tolerance in tomato (Solanum lycopresicum L.), a highly nutritious and economical vegetable, will have greater impact on the vegetable industry, especially in (semi) arid regions where salinity in soil and water are more prevalent. Besides, plants also experience salt stress when water in hydroponic system is recycled for tomato production. Grafting high yielding but salt-susceptible tomato cultivars onto salt-resistant/tolerant rootstocks is a sustainable strategy to overcome saline stress. Selection of salt-tolerant rootstocks though screening of available commercial and wild relatives of tomato under salt stress conditions is a pre-requisite for grafting. The positive response of grafting exerted by tolerant rootstocks or scion-rootstock interactions on yield and fruit characteristics of tomato under saline conditions is attributed to several physiological and biochemical changes. In this review, the importance of tomato grafting, strategies to select appropriate rootstocks, scion-rootstock interaction for growth, yield and quality characteristics, as well as the tolerance mechanisms that (grafted) plants deploy to circumvent or minimize the effects of salt stress in root zones are discussed. The future challenges of grafting tomato are also highlighted.
\end{abstract}

Keywords: Tomato grafting; salinity tolerance; rootstock; physio-biochemical mechanisms; Solanum lycopresicum L.

\section{Introduction}

Salinity in soil or water is a serious threat to plant growth that prevents plants in achieving their genetic potential. Salinity annually damages about $20 \%$ of the world's crops grown under irrigation [1]. The high salt content of productive arable lands could render half of this land unusable for agriculture by 2050 [1]. In the world's arid and semiarid areas, less rain, high evaporation, saline irrigation water and inefficient management of water leads to salinity problems. Approximately $20 \%$ of the total cultivated lands and 33\% of the irrigated agricultural lands worldwide are afflicted by high salinity and such areas are increasing at a rate of $10 \%$ per year [2]. It is estimated that about 3 ha of productive land per minute is lost due to salinity [3]. Thus, it is imperative to take appropriate measures timely to improve the salt tolerance of crops [4], especially tomato (Solanum lycopersicum 
L.), which enjoys the prime position worldwide among different vegetables owing to having high nutritional and economical significance.

Tomato is a member of the nightshade family and cultivated for fresh and processing purposes as an annual crop [5]. Additionally, this crop is used as a model plant to study physiology to molecular genetics and genomics in the angiosperms [6,7]. Salinity represents a substantive threat to tomato production [8]; it causes considerable reductions in tomato growth and yield [2]. Most commercial cultivars of tomato are considered to be moderately sensitive to salt stress, which affects seed germination and the vegetative and reproductive stages of growth $[5,9,10]$. Ongoing efforts to improve salt tolerance in tomato using plant breeding, biotechnological approaches and other management practices have met with limited success due to the genetic and physiological complexity of the traits involved in salt tolerance $[4,7,10,11]$. According to Rao et al. [12], improvement of salt tolerance using plant breeding is an intricate task because of the high number of traits involved, their quantitative nature, epistatic gene action, low to moderate heritability and high sensitivity to the environment. Genetic engineering has been used to increase salt tolerance in plants and has claimed some success [11,12], but its commercial success is still to be witnessed.

An environmentally friendly, sustainable and effective method is grafting that enables to exploit the benefit of resistant genotypes (as rootstocks) to improve the performance of commercial cultivars (as scion) that are susceptible to (a)biotic stresses [13]. Grafting offers an alternative to breeding and biotechnological approaches to rapidly enhance salt tolerance in vegetable plants $[8,11,14-16]$. This technique in woody perennial fruit plants has been a routine practice in Asia for more than 2000 years [14]. In herbaceous vegetables, grafting initially was practiced in 1920s in watermelon to increase resistance to soil-borne diseases [17]. After the first scientific publication about grafting [14,17], use of the technique spread to other cucurbitaceous and solanaceous vegetable crops to address soil-borne diseases and other environmental stresses [18,19]. Commercial tomato grafting became popular in the 1960s in East Asia, Europe and later in North America [20,21]. Application of vegetable grafting has spread in many countries by the end of the 1990s, but it got momentum only after the banning of methyl bromide (MB) in the Montreal protocol in 2005, particularly in developed countries. Although, the protocol was authorized until 2015 in developing countries, with the efforts of United Nations Industrial Development Organization (UNIDO), United Nations Development Program (UNDP), World Bank and lateral agencies from Europe, many developing countries (some of Latin America, Africa, Middle East and Asia) were able to control the use of MB well before 2015, and started using grafting as an alternative to MB [18]. MB was the most commonly used soil fumigant against deadly soil borne pathogens prevailing in intensive vegetables production in protected cultivation [22]. Besides, being a sustainable practice, grafting is a useful component of organic vegetable production, particularly of tomato. In recent pasts, the horizon of grafting use expanded to abiotic stresses too and among which, salinity got the most priority. For instance, watermelon produced in countries like Japan, Korea, Turkey, Greece and parts of Spain and Italy with almost $100 \%$ grafted seedlings, and the use of grafted plants is also increasing immensely in other vegetables like tomato, eggplant, pepper, cucumber and melons across the world [23]. In major countries where grafting is a popular technique, out of the total tomato cultivation proportion share of grafted tomato seedlings use is around 1\% in China, though it also ranks first in the number of grafted seedlings used, 25\% in Korea, 33\% in Vietnam, 40\% in Japan, 50\% in France and 75\% in Netherlands. In other countries like the USA, Italy, Morocco and Spain the uses of grafted seedlings were available in numbers, i.e., 18, 15.1, 44, 72.8 and millions [24,25]. In this review, we present an outline of the potential of a grafting tool to enhance salt tolerance in a tomato based on recent researches done across the world. We also propose a strategy for future research as well as adoption for its better exploitation for the growth of the agriculture sector. 


\section{Effect of Salinity on Tomato Plants}

Salinity is the most serious of all environmental stresses [26] and poses a great threat to agricultural sustainability [27]. It occurs when there is an excessive accumulation of salts (especially high $\mathrm{Na}^{+}$, $\mathrm{Cl}^{-}$and $\left.\mathrm{SO}_{4}{ }^{-}\right)$in the soil [28] or irrigation water $[11,16]$. The elevated level of salts generally causes a reduction of water potential in the root medium, thereby leading to a water deficit within plants $[5,29]$, besides their excess level can cause ion-toxicity and nutrient imbalance, especially of $\mathrm{K}^{+}, \mathrm{Ca}^{2+}$ and $\mathrm{Mg}^{2+}$ by disturbing their uptake and/or transport to the shoots [30].

In general, the main factor of inhibiting growth of salt stressed plants is elevated levels of $\mathrm{Na}^{+}$and $\mathrm{Cl}^{-}$; with roots remaining the primary sites for stress perception [31] and the subsequent responses at the cell, organ or whole plant levels [32]. According to the two-phase model of salt-induced growth reduction, plants suffer initially due to osmotic stress impairing their ability to absorb sufficient water, and then from salt specific injuries ascribed to, in general, toxic levels of $\mathrm{Na}^{+}$and $\mathrm{Cl}^{-}$interfering with key cellular processes and causing damage to the cell membranes and organelles; altering nutrient ratios, endogenous growth regulator concentrations and enzymatic activities and suppressing photosynthetic assimilation and causing plant death in the extreme cases [33]. In fact, the second phase of salinity stress, i.e., ion-specific toxicity, is a long-term process and depends on the intracellular salt ion levels, which mostly tend to increase with an increase in the magnitude and duration of salinity stress.

Salinity has been reported to disturb plants physiological and biochemical processes and induce changes in morphological characteristics that finally lead to losses in yield $[2,27,28,34]$. Salt stress causes decrease in plant height, shoot and root biomass and root length in tomato plants [35]. According to Najla et al. [36] salinity adversely affected plant height and leaf area, and the overall development process of tomato plants. However, the salinity induced decrease in plant height was more related to reduced internodal length than the number of nodes, and lower plant growth rate was associated with a decrease in leaflet growth and the number of leaflets per leaf in salt stressed plants [36]. The adverse effects of salinity on shoot and root morphology were the result of an alteration of plant physiology that includes altered absorption of water and nutrients, hormonal production and disrupted root to shoot signals [37]. Salt induced inhibition in photosynthesis and oxidative stress has been widely documented. Salt stress can also alter leaf metabolites concentrations as have been reported by Khavari-Nejad and Mostofi [38]. They observed a notable decrease in the level of chlorophyll and $\beta$-carotene contents, along with an increase of soluble sugars and total saccharides in the leaves of tomato plants treated with $100 \mathrm{mM} \mathrm{NaCl}$. In addition, aggregated chloroplasts and distorted and wrinkled cell membranes were also noticed in tomato leaves by these researchers. In spite of inhibiting plant height and shoots and roots dry matter contents, excess salt concentration in water reduced water use efficiency (WUE) and amount of $\mathrm{K}^{+}$and $\mathrm{K} / \mathrm{Na}$ ratio in all studied tomato cultivars [39]. The accumulation of monovalent and bivalent $\mathrm{Na}^{+}, \mathrm{K}^{+}$and $\mathrm{Ca}^{2+}$ ions in foliage and roots under saline conditions was, though, genotype-dependent [40]. Further, salinity affects almost all the plant growth stages, but the severity depends on the growth stage, salinity level and cultivar [35]. However, despite the inhibitory effects of salinity on growth and yield, the enhancement of some fruit quality characteristics (i.e., higher levels of sugars and organic acids) in tomato have been reported [41]. An increase of up to $40 \%$ carotenoid content in fruits of tomato plants exposed to moderate salinity has also been observed $\left(4.4 \mathrm{dS} \mathrm{m}^{-1}\right)$ [42].

\section{Grafting to Improve Salt Tolerance in Tomato}

\subsection{Growth and Yield}

The persuasive response of grafting on plant growth and yield characteristics under saline conditions can vary; this can be the result of intrinsic characteristics of scion, rootstock and their functional interactions, and severity of saline stress. A wide range of studies suggests that the adverse effects of salt stress on vegetable plants can be mitigated by grafting. Improved plant growth and yield performance of susceptible tomato cultivars under salt stress is the manifestation of positive response 
of grafting; these ascribed to the right choice of scion-rootstocks combination [11]. Concerning the response of scion-rootstock combination on tomato growth and yield, grafting 'Cuore di Bue' scion onto 'Arnold' rootstock was found superior to either non-grafted or those grafted onto other rootstocks ('Maxifort' and 'Armstrong') under a moderate salinity level $(20 \mathrm{mM} \mathrm{NaCl})$, while the response of rootstock grafting was not evident at higher $\mathrm{NaCl}$ concentration $(40 \mathrm{mM})$ [43]. The response of different rootstocks to salt susceptible scion 'Moneymaker' varied for yield and fruit parameters under saline conditions; graft combination involving 'Beaufort' and 'He-man' rootstocks was more productive under a mild saline condition. However, between two, only 'He-man' rootstock could provide sustenance to susceptible scion 'Moneymaker' for fruit yield under a high level of salinity. Contrarily, 'HPG' and 'Energy' rootstocks grafted tomatoes showed negative effect and produced lower yields [15].

Salt stress decreased both vegetative growth (i.e., stem diameter, plant height and shoot fresh weight) and fruit yield of both grafted and non-grafted plants. At this salinity level $\left(3.76 \mathrm{dS} \mathrm{m}^{-1}\right)$, no significant decrease in fruit yield was noticed in grafted plants ('Faridah' scion onto 'Unifort' rootstock) [10]. Concerning scion-rootstock combinations, a significant variation in plant growth (e.g., stem growth rate) was observed under saline conditions by Balliu et al. [44], who revealed that 'Charlotte' grafted onto 'Cyndia' exhibited higher mean stem growth rate than non-grafted plants. However, no difference in this parameter was noted between grafted and non-grafted tomato plants under normal (non-saline) condition. These authors, further stated that 'Bona' plants grafted onto 'Energy' rootstock produced higher mean yield compared to non-grafted plants, while this combination displayed lowest stem growth rate. The other scion, 'Charlotte', gave the maximum yield with rootstock 'Prospero' under saline conditions. The performance of salt sensitive cultivar 'Moneymaker' improved in terms of both plant growth and fruit yield under salt stress $(50 \mathrm{mM} \mathrm{NaCl})$, when it was grafted onto the salt tolerant rootstock 'Pera' [45]. Santa-Cruz et al. [46] reported that the 'UC-82B'/'Kyndia' (scion/rootstock) combination showed a tolerance response to excess salt (100 mM $\mathrm{NaCl}$ ) by producing higher shoot growth and fruit yield than the rest of the other graft combinations. Among yield-contributing traits, fruit weight was found to be the single factor to determine yield, while the number of fruits affected was not significantly affected by salt stress; as also was obvious in this study where graft combination 'UC-82B'/'Kyndia' exhibited higher fruit weight. Al-Harbi et al. [10] concluded that tomato could be grown successfully with a satisfactory yield by grafting onto suitable rootstock under salt stress (EC $3.76 \mathrm{dS} \mathrm{m}^{-1}$ ). While comparing the response of tomato grafting onto different rootstocks under saline conditions in indoor or outdoor grown plants, Voutsela et al. [47] revealed that tomato fruit yield was significantly higher in grafted plants than non-grafted plants in both indoor and outdoor grown plants under salt stress $(6.0 \mathrm{mS} / \mathrm{cm})$. The benefit of grafting for increased fruit yield over non-grafted plants under salt stress was more pronounced in indoor condition (from 208\% to 259\%) than outdoor condition (from $0 \%$ to $149 \%$ ). These workers have also reported significantly higher fruit yield in salt stressed self-grafted plants than non-grafted plants regardless of growing conditions. However, Iseri et al. [48] stated that enhanced salt tolerance and adaptive response of tomato scions was rootstock dependent rather than graft-induced changes per se. These reports indicate that selection of rootstocks and scion cultivars to be made reasonably for harnessing the benefit of grafting in tomato under saline conditions.

\subsection{Fruit Quality}

Despite the reduction of the fruit yield, enhancement of fruit quality traits is a general response of mild stress (i.e., water and salt); these are due to the accumulation of more metabolite contents under stress conditions. The interaction between grafting and salinity for fruit quality traits may be positive, negative or even neutral under stress conditions. The response of grafting on growth and fruit yield was positive when tomato cultivar 'Cuore di Bue' grafted onto 'Arnold' rootstock, whereas no obvious effect of grafting was observed in this graft combination on fruit quality traits (i.e., total soluble solids, fruit dry matter percentage, titratable acidity and TA) at any of the levels of $\mathrm{NaCl}$ (i.e., 0,20 or $40 \mathrm{mM}$ ) added medium [43]. Similarly, grafting 'Durinta' onto 'He-man' rootstock showed promising 
response for yield traits, especially under high saline medium $\left(8.8 \mathrm{dS} \mathrm{m}^{-1}\right)$, but the fruits of this graft combination had low titratable acidity content [15]. Turhan et al. [49] have also reported a reduction in the tomato fruit quality in grafted plants than non-grafted plants under salt stress. Contrary to these, findings of Balliu et al. [44] reported positive response of both grafting and salinity level; the fruit quality characteristics namely fruit dry matter percentage, vitamin $C$ and total soluble solids contents increased in grafted plants with the increase of $\mathrm{NaCl}$ concentration from 0 to $5 \mathrm{mM}$. Flores et al. [50] noticed that grafting 'Moneymaker' onto 'UC82B' did not increase fruit yield either under optimal or saline condition, fruit yield rather decreased in grafted plants, but fruit quality parameters (i.e., soluble solid content and titratable TA) were higher in grafted plants, more conspicuously under salt stress condition $(50 \mathrm{mM})$. However, grafting 'Moneymaker' onto 'Radja' rootstock was found as promising as both fruit yield and quality were increased in this graft combination under a saline condition (25 and $50 \mathrm{mM} \mathrm{NaCl}$ [ [50]. The inference drawn from these is that the combination of scion and rootstock should be selected carefully to get the maximum benefit of the grafting technique.

\section{Mechanisms of Salt Tolerance in Grafted Plants}

In order to overcome the harmful effects of salinity, grafted tomato plants employ certain adaptive strategies such as salt exclusion or retention, osmotic adjustment, activation of antioxidant defense system, nutrient homeostasis, plant hormonal balances and a gene expression led favorable response. Roots being the primary plant organ have to face any soil related stress (e.g., salinity); their intrinsic characteristics would determine overall plants performance.

\subsection{Morpho-Physiological Traits}

\subsubsection{Root System Architecture and Salt Tolerance}

Performance of grafted plants compared to non-grafted or self-grafted plants under a stressful condition is often dependent on the rootstock's root system characteristics; a vigorous root system could be the most important criterion for increasing salt tolerance [44]. The rootstock's root systems architecture specified by root length and density, root hairs and root surface area plays a critical role in ion and water uptake, thus determining salt tolerance of grafted plants [11,51]. A vigorous root system, for instance, produced more cytokinins and transported water to the shoot system by xylem sap, which positively affected plant growth and crop yield [44,52]. Furthermore, hydraulic conductivity of the roots may control plant growth by manipulation of the water supply to epigeous plant parts [53]; however, this process is still not clear. Roots being the primary organ exposed to salt stress, salt induced inhibition of root growth is quite obvious. For instance, salt stress (100 and $150 \mathrm{mM} \mathrm{NaCl})$ invariably reduced root growth of both control and grafted tomato plants, but the rate of root dry mass reduction was lesser in grafted plants (on 'ZhezhenNo.1' rootstock) than non-grafted plants. However, no effect of grafting was observed on either epigeous or hypogeous dry mass under non-saline $(0 \mathrm{mM}$ $\mathrm{NaCl}$ ) conditions [51]. Martínez-Rodríguez et al. [54] studied tomato rootstocks 'Radja' and 'Pera' for salt tolerance and they found that 'Radja' had a unique root genotype for salt tolerance with the ability to decrease salt ion transportation to the shoot system, as indicated by a lower ion concentration in the leaves. 'Pera' has the ability to improve salt tolerance in plants cultivated at any salt stress level. Tomato scion (cv. 'Faridah') grafted onto rootstock 'Unifort' was less affected by excess salt than the non-grafted scion; reflecting that 'Unifort' roots had a better capacity to limiting the transport of $\mathrm{Na}^{+}$and $\mathrm{Cl}^{-}$to above-ground parts [10]. Similar results were also recorded in cucumber grafted onto a figleaf gourd differing in their ability to regulate water and salt absorption and subsequent translocation to the scion [55].

\subsubsection{Plant Water Relations}

Plant water relations can be measured through root hydraulic conductance by estimating the nutrient and water uptake in grafted plants [56]. Rootstocks confer to grafted plants a stronger 
and larger root system, which provide an increase in minerals and water uptake in comparison to non-grafted plants [57]. Rootstocks mainly set roots physical characteristics, such as its enhanced uptake capacity or vertical and lateral expansion, rendering water uptake more facilitated. Water and nutrients uptake have been found more efficiently in a vigorous rootstock than scion roots [58]. Root hydraulic conductance was higher in grafted plants due to higher resistance of the graft union to water-flow [59]. Shalhevet et al. [60], Munns and Passioura [61] and Evlagon et al. [62] reported that hyperosmotic stress and ionic imbalance caused by the high apoplastic concentrations of $\mathrm{Na}+$ and $\mathrm{Cl}^{-}$. The decrease in root hydraulic conductance could be closely related to the decrease in the activity or concentration of aquaporins in the root plasma membrane due to increased salinity [63]. An experiment conducted by Estañ et al. [64] on tomato illustrated that, in order to exclude salts, various tomato genotypes' roots were used as rootstocks for a commercial tomato hybrid (cv. 'Jaguar'). Estañ and his collaborators noted that especially at 50 and $75 \mathrm{mM} \mathrm{NaCl}$, the 'Jaguar'/'Jaguar' combination plants demonstrated equal or paradoxically higher leaf water contents than the other grafting combinations, indicating that the 'Jaguar' rootstock was capable in salinity conditions to maintain water uptake. The rootstock-scion vascular connection played an important role in determining water and nutrient translocation, which mainly depends on the rootstock's vigorous root system [58,65], enhanced production of endogenous-hormones [66] and enhancement of scion vigor [67].

\subsubsection{Ion Uptake}

Studies have shown that rootstocks protect the scion shoots from salt damage mainly by reducing the ionic stress, and to some extent, by increasing the translocation of $\mathrm{K}^{+}, \mathrm{Ca}^{2+}$ and $\mathrm{Mg}^{2+}$ to the shoots and leaves; whereas they have little role in reducing the osmotic stress [68,69]. Reduced translocation of $\mathrm{Na}^{+}$and/or $\mathrm{Cl}^{-}$to the shoot system is achieved either by exclusion or restricted absorption by the roots [54,64]. Pérez-Alfocea et al. [70] opined that depending on the salt source plants employ its intrinsic potential to exclude $\mathrm{Na}^{+}$and/or $\mathrm{Cl}^{-}$from shoots by maintaining energy consuming the root toxic ion efflux. The positive effects of grafting on salt tolerance in a tomato was widely attributed to restricted entry of $\mathrm{Na}^{+}$and $\mathrm{Cl}^{-}$ion in epigeous biomass [10,64,71], though grafted plants were able to accumulate more nutrient elements (e.g., $\mathrm{Ca}^{2+}$ and $\mathrm{K}^{+}$) in the leaves than normal plants under saline stress [10]. Similarly, tomato cultivars 'Fanny' and 'Goldmar' grafted onto rootstock 'AR-9704' showed differential accumulation of $\mathrm{Na}^{+}$and $\mathrm{Cl}^{-}$, with $\mathrm{Cl}^{-}$and $\mathrm{Na}^{+}$concentrations being significantly higher in non-grafted than in grafted plants in both the cultivars and 'Fanny', respectively [72]. Semiz and Suarez [73] reported improved performance of tomato scion cv. 'Big Dena' grafted onto 'Maxifort' rootstock across five tested salinity levels; the positive response of grafting was attributed to a lesser concentration of $\mathrm{Na}^{+}$in the leaves of a grafted tomato than non-grafted plants. However, these researchers could not find any relation between $\mathrm{Cl}^{-}$in irrigation water and yield in a tomato. Apart from osmotic balance and root exclusion or restricted root-to-shoot translocation of the toxic ion (i.e., $\mathrm{Na}^{+}$), the third strategy that plants employ is ion accumulation and subsequent partitioning among the plant organs or compartmentalization in cellular organs such as vacuoles that eases toxic effects of salts. For instance, tomato scions grafted onto rootstock 'Arnold' tended to partition a bulk of shoot $\mathrm{Na}^{+}$into older leaves and thus reduced $\mathrm{Na}^{+}$levels in the actively growing younger leaves. This allowed the grafted plants to maintain favorable $\mathrm{K}^{+} / \mathrm{Na}^{+}, \mathrm{Ca}^{2+} / \mathrm{Na}^{+}$and $\mathrm{Mg}^{2+} / \mathrm{Na}^{+}$ratios in actively growing leaves [43].

The response of salt stress varies widely among Solanum species [37], besides salt concentration and exposure period also exert a severity response [64,74] In contrast to cultivated tomatoes (Solanum lycopersicum L.) that are moderately sensitive to salt stress, certain wild species are reportedly salt resistant. Unlike the cultivated tomato that generally excludes the salt ions $[2,54,75,76]$, most of the wild types (e.g., S. peruvianum [77], S. cheesmaniae [78], Lycopersicon pimpinellifolium, L. hirsutum and L. pennellii [79]) accumulate higher concentrations of $\mathrm{Na}^{+}$and $\mathrm{Cl}^{-}$in the leaves. However, there are some salt tolerant tomato ecotypes (e.g., 'Edkawy' and 'Pera') $[75,80,81]$ that exhibit a pronounced salt inclusion capacity similar to the salt-loving wild species. This implies that tolerance or sensitivity to 
salt would depend on the ability of a genotype (excluder or includer) to maintain benign ion levels through mechanisms like root exclusion, phloem recirculation and dilution such that physiological homeostasis is not disturbed [82]. If ion levels exceed the critical threshold, salt tolerance capacity diminishes, adversely affecting growth and fruiting. Use of salt tolerant types as rootstocks can protect the sensitive types from deleterious effects of salinity [54,64].

$\mathrm{He}$ et al. [51] found that with the enhancement of $\mathrm{NaCl}$ concentration, the $\mathrm{Na}^{+}$levels in leaves and roots increased considerably. They estimated that non-grafted, self-grafted and plants of scion-rootstock combinations elicited the same levels of $\mathrm{Na}^{+}$in leaves and roots under similar salt concentrations, whereas $\mathrm{K}^{+}$concentration in both leaves and roots decreased considerably with higher $\mathrm{NaCl}$ levels. Nevertheless, the roots of scion-rootstock grafted plants showed more $\mathrm{K}^{+} / \mathrm{Na}^{+}$ratio and water use efficiency (WUE) at $150 \mathrm{mM} \mathrm{NaCl}$ concentration than non-grafted and self-grafted plants.

In another study, Santa-Cruz et al. [46] selected tomato cultivars 'Moneymaker' (indeterminate growth habit, shows excluder character under salt stress) and 'UC-82B' (determinate growth habit and shows includer behavior) as scions, and tomato hybrid 'Kyndia' as a rootstock for the study of grafting behavior under 50 and $100 \mathrm{mM} \mathrm{NaCl}$ salt stress. Grafting had a positive effect on salt tolerance of scion 'UC-82B' grafted onto 'Kyndia' rootstock in terms of the shoot biomass at a $100 \mathrm{mM} \mathrm{NaCl}$ concentration. The same combination was noted for higher water content in leaves under salt stress compared to self-grafted 'UC-82B' plants. Accumulation of $\mathrm{Na}^{+}$and $\mathrm{Cl}^{-}$ions in leaves varied with the graft combination. Lower $\mathrm{Na}^{+}$and similar $\mathrm{Cl}^{-}$concentration was found in the 'Moneymaker' and 'Kyndia' combination as compared to self-grafted 'Moneymaker' plants. However, this response was different for the 'UC-82B' and 'Kyndia' combination, which elicited lower accumulation of both $\mathrm{Na}^{+}$ and $\mathrm{Cl}^{-}$ions. $\mathrm{Na}^{+} / \mathrm{K}^{+}$ratio in leaves of this combination decreased three times compared to self-grafted plants of 'UC-82B'. The toxic effect of ions was mitigated by the 'UC-82B' and 'Kyndia' combination.

The improvement in salt tolerance of tomato plants was related to a high leaf $\mathrm{K}^{+}$content in many studies $[51,83,84]$, though the direct relationship between leaf $\mathrm{K}^{+}$homeostasis and salinity tolerance of grafted plants has not been yet adequately worked out [11]. Studying the response of tomato cv. 'Faridah' onto 'Unifort' rootstock under saline conditions, fruit yield, $\mathrm{Ca}^{2^{+}}$and $\mathrm{K}^{+}$ions were noticeably higher in grafted plants compared to non-grafted plants. Besides, accumulation of $\mathrm{Na}^{+}$and $\mathrm{Cl}^{-}$was lower than in non-grafted tomato plants, under salt stress condition [10].

\subsection{Gas Exchange Attributes}

One of the early responses of glycophytes to salt stress is manifested as a reduction in leaf growth that seems to be caused by a decrease in stomatal conductance in tomato [85]. Stomatal factors decrease the photosynthetic rate in salt treated grafted and non-grafted plants by adversely affecting $\mathrm{CO}_{2}$ diffusion into leaves as a result of impaired stomatal and mesophyll conductance [86]. Salt stress blocks photosynthesis by suppressing the electron transport chain, which leads to the photoinhibition of photosynthesis. The inhibition of photosynthesis causes a reduction in the plant growth. In previous reports, it is established that grafting of salt tolerant rootstocks can enhance the photosynthetic rate by protecting the structure of chloroplast and alleviating the oxidative damage, which ultimately leads to the delay in the rate of photoinhibition $[87,88]$.

The rate of net photosynthesis under salt stress was higher in tomato plants (cv. 'Durinta') grafted onto 'Energy', 'He-man' and 'Resistar' rootstocks, though no significant effect of grafting on epigeous dry matter was noticed [15]. High photosynthetic rates as well as WUE were reported by He et al. [51] in tomato plants (cv. 'Hezuo903') grafted onto 'Zhezhen No.1' rootstock under severe salt stress. However, comparing the response of four tomato cultivars ('Jenin1,' 'Hebron,' 'Ramallah' and 'Maramand') under four salinity levels (0, 50, 100 and $150 \mathrm{mM} \mathrm{NaCl}$ ), Sholi [5] reported that the higher salt tolerance (up to $100 \mathrm{mM} \mathrm{NaCl}$ ) in cultivar 'Ramallah' was attributed to the highest photosynthesis rate along with $\mathrm{K}^{+} / \mathrm{Na}^{+}$ratio than the others.

Two commercial hybrid tomato cultivars, 'Belle' and 'Gardel' scions grafted on two interspecific hybrids, 'Beaufort' and 'Maxifort' rootstock showed no significant effect on net photosynthesis and 
stomatal conductance when exposed to $\mathrm{NaCl}$ compared to the non-grafted plants [89]. Feng et al. [90] also found that salinity treated tomato scion grafted on wolfberry (Lycium chinense) rootstock displayed higher net photosynthesis, transpiration, stomatal conductance, Fv/Fm and electron transport rate in comparison with non-grafted tomato plants.

\subsection{Molecular Responses}

Salt stress sets in motion a chain of events-reduced stomatal conductance, decreased photosynthetic electron transport and increased production of harmful reactive oxygen species (ROS) - that lead eventually to plant damage and death. ROS (e.g., hydrogen peroxide and superoxide radicals), by causing oxidative damage to the proteins, nucleic acid and lipids, disturbs the plant metabolism. Both enzymatic (i.e., ascorbate peroxidase (APX), catalase (CAT), superoxide dismutase (SOD), monodehydro ascorbate reductase, dehydro ascorbate reductase and glutathione reductase (GR)) and non-enzymatic (i.e., reduced glutathione, reduced ascorbate, carotenoids and tocopherols) antioxidant systems are activated by the plants to minimize ROS-induced oxidative damage. In grafted plants, salt-induced production of ROS generally remains quite low than in non-grafted plants as evidenced by a significant increase in the antioxidant activity in salt-treated (grafted) tomatoes. While SOD and CAT activities tended to increase with an increase in salinity in grafted plants, the reverse was true for non-grafted and self-grafted plants [51]. Besides enzymatic antioxidants, a non-enzymatic antioxidant system (ascorbate peroxidase, monodehydro ascorbate reductase, reduced glutathione, etc.) is also known to remove the excess ROS [91]. Higher expression of CAT mRNA, $\mathrm{Cu} / \mathrm{Zn}-\mathrm{SOD}, \mathrm{Mn}-\mathrm{SOD}$ and higher activities of CAT, $\mathrm{Cu} / \mathrm{Zn}-\mathrm{SOD}, \mathrm{Mn}-\mathrm{SOD}$ and SOD have been observed in salt stressed grafted plants [92]. Grafted eggplant produced lower $\mathrm{O}_{2-}, \mathrm{H}_{2} \mathrm{O}_{2}$ and MDA compared to non-grafted seedlings when subjected to $\mathrm{Ca}\left(\mathrm{NO}_{3}\right)_{2}$ stress. Higher activities of $\mathrm{SOD}, \mathrm{APX}$ and GR were also seen in grafted than in non-grafted seedlings [93]. Ruiz et al. [94] explored a salt tolerance ability in another solanaceous species: tobacco (Nicotiana spp.) and a tomato-tobacco (scion-rootstock) combination (named as 'Tomacco' by Yasinok et al. [95]). Tobacco roots, in fact, were able to restrain the concentration of $\mathrm{Na}^{+}$and $\mathrm{Cl}^{-}$, and lipid peroxidation in their leaves, besides inducing an accumulation of proline and sucrose concentrations under saline conditions [94]. The ability of tobacco roots in conferring better adaptive responses to salt stress in comparison to tomato was supported by the upregulation of proline and antioxidant enzymes (APOX and CAT) levels in grafted plants [48].

The commercial cultivars of tomato show more or less sensitivity to salt stress [96] and undergo drastic losses due to salts [97]. The genetics of this trait specific in tomato have also been discussed nicely by Cuartero et al. [34]. In tomato, a universal stress protein gene (SpUSP) cloned from S. pennellii, which is a wild relative of tomato and functionally characterized in commercial tomato genotype revealed enhanced expression under stress conditions such as dehydration, salt, oxidative and abscisic acid (ABA) treatment. About 15 primers were synthesized using fifteen salinity responsive candidate genes. The results from these primers displayed that the genotype UC82B showed the maximum vegetative growth parameters and yield, so, exploitation of this identified genotype could be as used for the salt tolerance [97]. Most recently in 2020, Yveline et al. [98] noticed that the salinity tolerant accessions collected from the Islands of Galapagos use different mechanisms to survive under salt stress conditions, which exhibited natural diversity among the Galapagos tomatoes for high salinity tolerance. They found some accessions namely LA0317, LA1449 and LA1403, which showed significantly higher tolerance under salt stress at the seedling stage. Their tolerance mechanism at the genetic and molecular level need to be studied intensively and comprehensively so that it could be helpful to develop salt tolerant commercial tomato cultivars to sustain tomato production under changing climate scenario across the globe. Such identified genotypes can be used as rootstocks in tomato grafting to raise the salinity tolerance of commercial scion cultivars after investigating their graft compatibility and subsequent effects on fruit characteristics.

Asins et al. [99] reported the genetic dissection of tomato rootstock effects on scion traits under moderate salinity. They documented that the rootstock HKT1 genotype affects the $\mathrm{Na}^{+}$level in fruits, 
which was found higher when the rootstock genotype was homozygote for SpHKT1. Along with this, they found the 37 QTLs, which controls the important rootstock-mediated scion traits such as the leaf concentration of nutrients, fruit yield, soluble-solids content of fruits and harvest time under moderate salinity.

In the salt-tolerance mechanism, it is now well established that calcium has an important role. The exogenous application of calcium can protect the plant from the negative effect of salinity [100]. The high amount of $\mathrm{Na}^{+}$can induce a calcium signaling cascade, which leads to the activation of the salt-overly-sensitive (SOS) pathway and stimulation of $\mathrm{Na}^{+} / \mathrm{H}^{+}$exchange [101]. An ER chaperone protein, Calreticulin, is considered as a regulating protein for the $\mathrm{Ca}^{2+}$ homeostasis by binding to $\mathrm{Ca}^{2+}$. Salt stress causes the calreticulin to bind with the $\mathrm{Ca}^{2+}$ ions, which later accumulated in the cell. The accumulated calcium ions act as a secondary messenger for ABA resulting into the ameliorations of salt stress [102]. Shaterian et al. [103] reported the effect of grafting and ABA on calreticulin gene expression in a potato. They observed an increase in the expression of calreticulin in salt stressed grafted plants and showed a positive association in the presence of abscisic acid.

\subsection{Growth Regulators}

During the past few decades, the role of phytohormones in modulating the union between shoot (scion) and root (rootstock) components in grafted plants has become a focal point of research: in addition to regulating key metabolic processes at the graft union, endogenous plant bio-regulators (e.g., auxins, gibberellins, cytokinins and ethylene) are also involved in signal transduction across the graft union [104]. Functions of some important phytohormones in grafted plants are briefly summarized in the following sections:

Auxins: While other phytohormones play minor roles, auxins, both alone and in interaction with other phytohormones, remain central to vascular tissue regeneration and connection, and thus to the growth and development of vascular tissues [105]. Two main protein families (PIN-FORMED auxin transport proteins (PINs) and proteins of ATP-binding cassette subfamily B (ABCB)) regulate a process called 'polar auxin transport' (PAT) that ensures the maintenance of adequate auxin levels for the proper development of xylem tissues [106]. For example, increased expression of CCPIN1b and CCLAX3 genes encoding the efflux carriers for PAT was found to induce graft union development in Carya cathayensis [107]. Similarly, Sauer et al. [108] found higher PIN1 expression at damaged stem portions to activate the process of xylem cell differentiation in pea (Pisum sativum). Transcriptome analysis of grafted Torreya grandis plants indicated that auxins modulate the key MAPK signaling pathway during graft development [109]. Auxins are also believed to enhance graft union by regulating metabolic pathways linked to phenylpropanoids, cytochrome P450 and carbohydrates. Available evidence suggests that besides promoting the formation of lateral roots, auxins also regulate xylem development and cambium growth, processes critical to the success of grafting in plants [104].

Cytokinins: The significant role of cytokinins (CKs) in callus proliferation at the graft union can be ascribed to their increased biosynthesis during the process of wound healing and to the elevated zeatin riboside levels at the graft unions [105]. CKs are known to stimulate the regeneration of vessels and sieve tubes. Moreover, CKs interact with the auxins to promote the vascular differentiation and increase the phloem/xylem ratio [110]. Increased levels of CKs in the rootstock xylem tend to induce auxin translocation from the aerial parts that in turn promotes the development of graft union [111]. Exogenously applied CKs accelerate the graft union and growth by enhancing the callus formation, phloem regeneration and soil nutrient supply to the scion $[112,113]$. While CKs alone are often less effective in modulating the development of vascular tissues, they act synergistically with other phytohormones (e.g., auxins) to enhance the cell division, xylem fiber development, cambium activity and regeneration of phloem/xylem tissues at the site of injury [114].

Since salinity stress decreased plant CK status, increasing root-to-shoot CK transport by using a rootstock overexpressing the CK biosynthesis genes such as isopentenyltransferase improved tomato salt tolerance by increasing vegetative and fruit growth and also delaying leaf senescence and 
maintaining stomatal conductance and PSII efficiency, thereby avoiding or delaying the accumulation of toxic ions [115].

Gibberellins: Gibberellins (GAs) are known to regulate the processes like cambium activity, xylem fiber differentiation and expansion, and secondary growth. Frequent movement of GAs across the graft union is believed to contribute to the union of shoot and root components, and to the normal development of vascular tissues; as evidenced by their involvement in the reunion of cortex in cucumber and tomato $[116,117]$. Since they hasten xylogenesis, GAs might also trigger vascular bundles formation at the graft union [118]. Experiments with mutants lacking GA-biosynthetic enzymes and wild type pea plants pointed to the role of GAs in regulating the normal growth of vascular tissues, induce the processes of wood formation, xylem expansion and cambial activity [119]. Development of a particular vascular tissue also depends on the ratio of auxins and GAs; while a higher IAA:GA ratio hastens xylem formation, low IAA:GA ratio promotes phloem formation [120]. These two hormones also act synergistically to regulate the cell division and secondary growth of the vascular tissues. For instance, GAs stimulate PAT by up-regulating the key auxin transporter PIN1 in the cambial region [119]. Up-regulation of the expression of GA20OX, a gene involved in GA-biosynthesis, points to increased biosynthesis of GAs at the site of graft union. Up-regulation of Cla015407, a gene encoding enzyme gibberellin 3-beta-hydroxylase involved in the conversion of GA20 to GA1, in grafted watermelons also supports the positive role of GAs in the growth and development of composite plants [121].

Abscisic acid: There is little evidence for any direct role of ABA in the growth and development of grafted plants; however, ABA seems to be indirectly involved in the processes of wound formation and vascular differentiation: abiotic stresses in general including wounding tend to hasten $A B A$ biosynthesis [122]. In contrast to ABA-deficient mutants, wild type plants display increased expression of wound-activated genes in response to ABA application [122,123]. Salinity enhances ABA concentration in shoot limiting water loss through transpiration (by inducing stomatal closure) and maintaining leaf water relations in plants grown under saline conditions. Chen et al. [124] reported that the scion genotype, and its ABA level, played the major role in the growth of grafted plants, regardless of the rootstock genotype and the salinity of the growth medium. Although ABA has been suggested to restrict the synthesis of the potential growth inhibitor ethylene, thus maintaining growth, in other circumstances such as citrus leaf abscission under salinity, ABA apparently stimulates 1-aminocyclopropane-1-carboxylic acid (ACC) synthesis [85]; these authors also reported that ratios between CKs and the ethylene precursor ACC were most closely correlated with both leaf biomass and PSII efficiency $(\mathrm{Fv} / \mathrm{Fm})$ of tomato grown under saline conditions whereas the ratio ACC/ABA was negatively correlated with leaf biomass.

Ethylene: Although ethylene signaling is implicated in tissue reunion in the wounded stems, it is hardly of any significance in the grafted hypocotyls, suggesting that differential roles of ethylene might be due to the differences in tissue age and type. Transcriptomic analyses of grafted Arabidopsis hypocotyls showed that ethylene biosynthesis genes are activated at the point of graft union [125]. However, mutating ANAC071 reduced the formation of vascular tissues at the graft junction [126]. Under salinity, ethylene production is quickly stimulated in plant tissues [127]. Ungrafted tomato genotype cv. Boludo F1 had 40\% higher ACC concentration in the xylem sap in comparison with plants grafted onto some low and high vigor rootstocks (derived from the recombined inbred line (RIL) population of Solanum lycopersicum $\times$ Solanum cheesmaniae) after growing for 50 days under moderate salinity $(75 \mathrm{mM} \mathrm{NaCl})$. Accumulation of the ethylene precursor ACC indicated the onset of salt-induced oxidative damage in the leaves, preceding leaf senescence induction and leaf growth impairment under salinity [85].

A summary of the main agronomic effects and physiological and molecular mechanisms of tomato grafted plants in comparison to non-grafted or self-grafted plants grown under non-saline and saline conditions is reported in Table 1 and Figure 1. 
Table 1. Selected examples of grafting combinations to improve salt stress tolerance in tomato.

\begin{tabular}{|c|c|c|c|c|c|c|}
\hline $\begin{array}{c}\text { Tomato } \\
\text { (S. lycopersicum L.) } \\
\text { Scion Cultivar and } \\
\text { Commercial source }\end{array}$ & $\begin{array}{c}\text { Rootstock } \\
\text { Species/Cultivar and } \\
\text { Commercial Source }\end{array}$ & Salt Treatments & $\begin{array}{l}\text { Growing } \\
\text { Conditions }\end{array}$ & Effects of Grafting & $\begin{array}{c}\text { Key Mechanisms of } \\
\text { Grafted Plant } \\
\text { Tolerance }\end{array}$ & Reference \\
\hline $\begin{array}{c}\text { 'Faridah' } \\
\text { (Golden Valley Seed) }\end{array}$ & $\begin{array}{c}\text { 'Unifort' }(S . \\
\text { lycopersicum } \times S . \\
\text { habrochaetes }) \\
(\text { DeRuiter Seed })\end{array}$ & $\begin{array}{c}\text { Fresh water }(0.52 \\
\left.\mathrm{dSm}{ }^{-1}\right) \text { and brackish } \\
\text { water }\left(3.76 \mathrm{dS} \mathrm{m}^{-1}\right)\end{array}$ & $\begin{array}{l}\text { Soil medium under } \\
\text { greenhouse }\end{array}$ & $\begin{array}{l}\text { High growth and } \\
\text { yield }\end{array}$ & $\begin{array}{c}\mathrm{Na}^{+} \text {and } \mathrm{Cl}^{-} \\
\text {exclusion; high } \mathrm{Ca}^{+2} \\
\text { and } \mathrm{K}^{+}\end{array}$ & Al-Harbi et al. [10] \\
\hline $\begin{array}{c}\text { 'Boludo' } \\
\text { (Seminis Vegetable } \\
\text { Seeds) }\end{array}$ & $\begin{array}{l}\text { RILs derived from } \\
\text { cross S. lycopersicum } \times \\
\text { S. cheesmaniae }\end{array}$ & $\begin{array}{c}75 \mathrm{mM} \mathrm{NaCl}^{(8.6} \\
\left.\mathrm{dSm}^{-1}\right) \text { designated as } \\
\text { moderate saline }\end{array}$ & $\begin{array}{l}\text { Nutrient solution } \\
\text { culture using } \\
\text { rockwool substrate, in } \\
\text { greenhouse } \\
\text { (long-term, } 120 \mathrm{~d})\end{array}$ & $\begin{array}{l}\text { High yield, leaf fresh } \\
\text { weight, Fv/Fm, }\end{array}$ & $\begin{array}{c}\text { High } \mathrm{K}^{+} \\
\text {concentration and } \\
\mathrm{K}+/ \mathrm{Na}+\text { ratio, and } \\
\text { cytokinins }\end{array}$ & Albacete et al. [84] \\
\hline $\begin{array}{c}\text { 'Boludo' } \\
\text { (Seminis Vegetable } \\
\text { Seeds] }\end{array}$ & $\begin{array}{l}\text { RILs derived from } \\
\text { Solanum lycopersicum } \\
\times \text { S. pimpinellifolium }\end{array}$ & $\begin{array}{l}75 \mathrm{mM} \mathrm{NaCl} \\
\left(8.94 \mathrm{dS} \mathrm{m}^{-1}\right)\end{array}$ & $\begin{array}{l}\text { Open soilless system } \\
\text { in coco fiber substrate, } \\
\text { in greenhouse } \\
(\text { long-term, } 234 \mathrm{~d})\end{array}$ & $\begin{array}{l}\text { High yield, fruit } \\
\text { quality and delay } \\
\text { fruit maturity }\end{array}$ & & Asins et al. [99] \\
\hline $\begin{array}{c}\text { ‘Charlotte' (NA), } \\
\text { 'Bona' } \\
\text { (Clause Seeds) }\end{array}$ & $\begin{array}{c}\text { 'Cyndia' (Lycopersicon } \\
\text { spp.) (NA) }\end{array}$ & $\begin{array}{c}0.0,2.5 \text { and } \\
5.0 \mathrm{mM} \mathrm{NaCl}\end{array}$ & $\begin{array}{l}\text { Natural soil and } \\
\text { Klasmann grow bags } \\
\text { as substrate under } \\
\text { greenhouse }\end{array}$ & $\begin{array}{l}\text { High growth and fruit } \\
\text { size but not yield. } \\
\text { Soluble solids and } \\
\text { ascorbic acids also } \\
\text { increased. }\end{array}$ & $\begin{array}{l}\text { Vigorous root system, } \\
\text { high growth. }\end{array}$ & Balliu et al. [44] \\
\hline $\begin{array}{l}\text { ‘Cuore di Bue' (Vita } \\
\text { Sementi Italian Seeds) }\end{array}$ & $\begin{array}{c}\text { 'Arnold' }(S . \\
\text { lycopersicum } \times S . \\
\text { habrochaites }) \\
\text { (Syngenta Seeds) }\end{array}$ & $\begin{array}{c}\mathrm{NaCl} \text { concentrations } \\
0,20 \text { and } 40 \mathrm{mM}\end{array}$ & $\begin{array}{l}\text { Nutrient solution } \\
\text { culture in pots } \\
\text { (perlite-peat } \\
\text { substrate; 3:1, v/v), in } \\
\text { greenhouse } \\
\text { (long-term; } 130 \mathrm{~d} \text { ) }\end{array}$ & $\begin{array}{l}\text { High marketable } \\
\text { yield }(23-33 \%)\end{array}$ & $\begin{array}{c}\text { Shoot } \mathrm{Na}^{+} \\
\text {partitioning to older } \\
\text { leaves (maintenance } \\
\text { of higher } \mathrm{K}^{+} / \mathrm{Na}^{+} \text {, } \\
\mathrm{Ca}^{2+} / \mathrm{Na}^{+}, \\
\text {and } \mathrm{Mg}^{2+} / \mathrm{Na}^{+} \text {ratios) }\end{array}$ & Di Gioia et al. [43] \\
\hline $\begin{array}{c}\text { 'Jaguar' } \\
\text { (Ramiro Arnedo S.A.) }\end{array}$ & $\begin{array}{c}\text { 'Radja', 'Pera', } \\
\text { 'Volgogradskij' } \\
\text { (S. lycopersicum L.) } \\
\text { (NA) }\end{array}$ & $\begin{array}{c}\text { Control, } 25,50 \text { and } \\
75 \mathrm{mM} \mathrm{NaCl} \\
\text { corresponding to EC } \\
\text { of } 2.3,4.8,4.8,7.3 \text { and } \\
9.1 \mathrm{dS} \mathrm{m}^{-1} \\
\text { respectively }\end{array}$ & $\begin{array}{l}\text { Nutrient solution } \\
\text { culture in pots } \\
\text { (siliceous sand), in } \\
\text { greenhouse }\end{array}$ & High yield & $\mathrm{Na}^{+}$and $\mathrm{Cl}^{-}$exclusion & Estañ et al. [64] \\
\hline
\end{tabular}


Table 1. Cont.

\begin{tabular}{|c|c|c|c|c|c|c|}
\hline $\begin{array}{c}\text { Tomato } \\
\text { (S. lycopersicum } \mathrm{L} .) \\
\text { Scion Cultivar and } \\
\text { Commercial source }\end{array}$ & $\begin{array}{c}\text { Rootstock } \\
\text { Species/Cultivar and } \\
\text { Commercial Source }\end{array}$ & Salt Treatments & $\begin{array}{l}\text { Growing } \\
\text { Conditions }\end{array}$ & Effects of Grafting & $\begin{array}{c}\text { Key Mechanisms of } \\
\text { Grafted Plant } \\
\text { Tolerance }\end{array}$ & Reference \\
\hline $\begin{array}{c}\text { 'Boludo' } \\
\text { (Seminis Vegetable } \\
\text { Seeds) }\end{array}$ & $\begin{array}{l}\text { RIL's of cross } S \text {. } \\
\text { lycopersicum } \times S \text {. } \\
\text { pimpinellifolium }\end{array}$ & $\begin{array}{c}75 \text { and } 125 \mathrm{mM} \mathrm{NaCl} \text {, } \\
\text { corresponding } \mathrm{EC} \\
\text { value of } 8.6 \text { and } \\
13.7 \mathrm{dS} \mathrm{m}{ }^{-1} \\
\text { respectively }\end{array}$ & $\begin{array}{l}\text { Nutrient solution } \\
\text { culture in fiber } \\
\text { coconut } \\
\text { coast, in greenhouse } \\
\text { (long-term, } 120 \mathrm{~d} \text { ) }\end{array}$ & High fruit yield & $\begin{array}{l}\text { Useful QTL's favoring } \\
\text { salt tolerance to } \\
\text { rootstocks }\end{array}$ & Estañ et al. [6] \\
\hline $\begin{array}{c}\text { 'Fanny', 'Goldmar' } \\
\text { (NA) }\end{array}$ & $\begin{array}{c}\text { 'AR-9704' } \\
\text { (S. lycopersicum) (NA) }\end{array}$ & 0 and $75 \mathrm{mM} \mathrm{NaCl}$ & $\begin{array}{l}\text { Hydroponic system, } \\
\text { in controlled } \\
\text { condition (short } \\
\text { duration, } 10 \mathrm{~d} \text { salt } \\
\text { treatment) }\end{array}$ & $\begin{array}{l}\text { Similar hydraulic } \\
\text { conductance }\end{array}$ & $\mathrm{Na}^{+}$and $\mathrm{Cl}^{-}$exclusion & $\begin{array}{c}\text { Fernández-García et } \\
\text { al. [59] }\end{array}$ \\
\hline 'Fanny' (NA) & $\begin{array}{c}\text { 'AR-9704' } \\
\text { (S. lycopersicum) (NA) }\end{array}$ & $\begin{array}{c}0,30 \text { and } 60 \mathrm{mM} \mathrm{NaCl} \\
\text { corresponding } \mathrm{EC} \text { of } \\
2.3,5.3 \text { and } \\
8.3 \mathrm{dS} \mathrm{m}^{-1}, \\
\text { respectively }\end{array}$ & $\begin{array}{l}\text { Nutrient solution } \\
\text { culture- in perlite sacs, } \\
\text { in greenhouse }\end{array}$ & $\begin{array}{l}\text { High growth and } \\
\text { stomatal conductance }\end{array}$ & $\begin{array}{c}\mathrm{Na}^{+} \text {and } \mathrm{Cl}^{-} \text {exclusion } \\
\text { by shoot }\end{array}$ & $\begin{array}{c}\text { Fernández-García et } \\
\text { al. [72] }\end{array}$ \\
\hline $\begin{array}{c}\text { 'Kyndia', } \\
\text { ‘Moneymaker' (HL), } \\
\text { 'Boludo' (Seminis } \\
\text { Vegetable Seeds) }\end{array}$ & $\begin{array}{l}\text { 'UC832B', Pera, Radja } \\
\text { (S. lycopersicum) and } \\
\text { RILs of cross } S \text {. } \\
\text { lycopersicum } \times \text { S. } \\
\text { cheesmaniae (NA) }\end{array}$ & $\begin{array}{c}0,20,50 \text { and } 75 \mathrm{mM} \\
\mathrm{NaCl} \text { corresponding } \\
\mathrm{EC} 2.2,4.5,7.0 \text { and } \\
9.5 \mathrm{dSm}^{-1} \\
\text { respectively }\end{array}$ & $\begin{array}{l}\text { Nutrient solution } \\
\text { culture in pots } \\
\text { (coconut fiber } \\
\text { substrate), in } \\
\text { greenhouse }\end{array}$ & $\begin{array}{l}\text { Fruit yield and } \\
\text { especially the fruit } \\
\text { quality (soluble solids } \\
\text { and titratable acidity) }\end{array}$ & - & Flores et al. [50] \\
\hline $\begin{array}{l}\text { ‘Hezuo903’ (Jiangsu } \\
\text { Seed) }\end{array}$ & $\begin{array}{c}\text { 'Zhezhen No. 1' } \\
\text { (S. lycopersicum) (NA) }\end{array}$ & $\begin{array}{c}0,50,100 \text { and } 150 \mathrm{mM} \\
\mathrm{NaCl} \text { concentration }\end{array}$ & $\begin{array}{l}\text { Nutrient solution } \\
\text { culture in pots, in } \\
\text { controlled condition } \\
\text { (short duration; } \\
\text { 2-weeks) }\end{array}$ & High plant growth & $\begin{array}{l}\text { High photosynthetic } \\
\text { and antioxidant } \\
\text { activities; but similar } \\
\qquad \mathrm{Na}^{+} \text {and } \mathrm{Cl}^{-}\end{array}$ & He et al. [51] \\
\hline
\end{tabular}


Table 1. Cont.

\begin{tabular}{|c|c|c|c|c|c|c|}
\hline $\begin{array}{c}\text { Tomato } \\
\text { (S. lycopersicum L.) } \\
\text { Scion Cultivar and } \\
\text { Commercial source }\end{array}$ & $\begin{array}{c}\text { Rootstock } \\
\text { Species/Cultivar and } \\
\text { Commercial Source }\end{array}$ & Salt Treatments & $\begin{array}{l}\text { Growing } \\
\text { Conditions }\end{array}$ & Effects of Grafting & $\begin{array}{c}\text { Key Mechanisms of } \\
\text { Grafted Plant } \\
\text { Tolerance }\end{array}$ & Reference \\
\hline $\begin{array}{l}\text { 'Elazig' } \\
\text { (LC) }\end{array}$ & $\begin{array}{c}\text { 'Hasankeyf' } \\
\text { (Nicotiana tabacum); } \\
\text { 'Samsun' N. rustica) }\end{array}$ & $\begin{array}{c}0.2,0.4 \text { and } 0.6 \mathrm{M} \\
\mathrm{NaCl}\end{array}$ & $\begin{array}{l}\text { In pots, in control } \\
\text { condition (short } \\
\text { duration; } 10 \mathrm{~d} \text { salt } \\
\text { treatment) }\end{array}$ & $\begin{array}{l}\text { High shoot growth } \\
\text { (stem elongation and } \\
\text { leafing) }\end{array}$ & $\begin{array}{l}\text { High proline content } \\
\text { and antioxidant } \\
\text { activity (ascorbate } \\
\text { peroxidase }(\mathrm{APX}) \text { and } \\
\text { catalase }(\mathrm{CAT}))\end{array}$ & Iseri et al. [48] \\
\hline 'Moneymaker' (HL) & $\begin{array}{c}\text { 'Radja', 'Pera' } \\
\text { (S. lycopersicum) (NA) }\end{array}$ & $\begin{array}{c}0,25 \text { and } 50 \mathrm{mM} \text { (I } \\
\text { expt.) and } 75,150 \text { and } \\
225 \mathrm{mM}(\mathrm{II} \text { expt.) } \\
\mathrm{NaCl}\end{array}$ & $\begin{array}{l}\text { Nutrient solution } \\
\text { culture in pots under } \\
\text { greenhouse }\end{array}$ & High fruit yield & $\begin{array}{l}\mathrm{Na}+\text { and } \mathrm{Cl}- \\
\text { exclusion }\end{array}$ & $\begin{array}{c}\text { Martínez-Rodríguez } \\
\text { et al. [54] }\end{array}$ \\
\hline $\begin{array}{c}\text { 'Durinta' } \\
\text { (Western Seeds) }\end{array}$ & $\begin{array}{c}\text { 'He-man' } \\
\text { (Syngenta seeds) }\end{array}$ & $\begin{array}{c}2.8 \text { (control) and } \\
8.8 \mathrm{dS} \mathrm{m}^{-1} \text { by adding } \\
\mathrm{NaCl}\end{array}$ & $\begin{array}{l}\text { Open soilless system, } \\
\text { in pots (sand } \\
\text { substrate), in } \\
\text { greenhouse }\end{array}$ & High fruit yield & $\begin{array}{c}\text { High net } \\
\text { photosynthesis }\end{array}$ & Martorana et al. [15] \\
\hline $\begin{array}{c}\text { ‘Gokce }(191)^{\prime} \text { (Zeraim } \\
\text { Gedera) }\end{array}$ & $\begin{array}{c}\text { 'Vigomax' (De Ruiter } \\
\text { seed) 'Yedi' } \\
\text { (L. esculentum } \times \text { L. } \\
\text { hirsutum) (Rijk } \\
\text { Zwaan) }\end{array}$ & $\begin{array}{l}50,100,150,200,250 \\
\text { and } 300 \mathrm{mM}\end{array}$ & $\begin{array}{l}\text { Nutrient solution } \\
\text { culture on Styrofoam, } \\
\text { in greenhouse (15 d } \\
\text { salt treatment) }\end{array}$ & $\begin{array}{l}\text { Least leaf damage } \\
\text { and high leaf number, } \\
\text { stem thickness }\end{array}$ & $\begin{array}{l}\text { High antioxidant } \\
\text { activity (CAT, POX) }\end{array}$ & $\begin{array}{c}\text { Oztekin and Tuzel } \\
\text { [52] }\end{array}$ \\
\hline $\begin{array}{l}\text { ‘Moneymaker' } \\
\text { (HL) }\end{array}$ & $\begin{array}{c}\text { 'Pera' } \\
(\text { S. lycopersicum) (NA) }\end{array}$ & $\begin{array}{c}50 \mathrm{mM} \mathrm{NaCl}^{(\mathrm{EC}}, \\
\left.6.5 \mathrm{dSm}^{-1}\right), \text { without } \\
\text { control }\end{array}$ & $\begin{array}{l}\text { In soil with } \\
\text { fertigation system } \\
\text { under greenhouse } \\
\quad \text { (long term) }\end{array}$ & $\begin{array}{l}\text { High fruit yield and } \\
\text { fruit number }\end{array}$ & $\begin{array}{c}\text { High } \mathrm{Na}^{+} \text {and } \mathrm{Cl}^{-} \\
\text {but similar osmotic } \\
\text { potential and high } \mathrm{K}^{+}\end{array}$ & $\begin{array}{l}\text { Santa-Cruz et al. } \\
{[45]}\end{array}$ \\
\hline $\begin{array}{c}\text { ‘UC-82B' } \\
\text { (Tecni seeds/Starke } \\
\text { Ayres seeds) }\end{array}$ & $\begin{array}{c}\text { 'Kyndia' } \\
\text { (S. lycopersicum) (NA) }\end{array}$ & $\begin{array}{l}\text { 0,50 and } 100 \mathrm{mM} \\
\mathrm{NaCl}\end{array}$ & $\begin{array}{l}\text { Nutrient solution } \\
\text { culture without (short } \\
\text { duration, } 35 \mathrm{~d} \text { ) or } \\
\text { with substrate } \\
\text { (siliceous sand, long } \\
\text { term, } 90 \mathrm{~d} \text { ) in } \\
\text { greenhouse }\end{array}$ & $\begin{array}{c}\text { Fruit yield and fruit } \\
\text { weight, shoot biomass }\end{array}$ & $\begin{array}{l}\mathrm{Na}+\text { and } \mathrm{Cl}- \\
\text { exclusion; low } \\
\mathrm{Na}^{+} / \mathrm{K}^{+} \text {ratio }\end{array}$ & $\begin{array}{l}\text { Santa-Cruz et al. } \\
{[46]}\end{array}$ \\
\hline
\end{tabular}


Table 1. Cont.

\begin{tabular}{|c|c|c|c|c|c|c|}
\hline $\begin{array}{c}\text { Tomato } \\
\text { (S. lycopersicum L.) } \\
\text { Scion Cultivar and } \\
\text { Commercial source }\end{array}$ & $\begin{array}{c}\text { Rootstock } \\
\text { Species/Cultivar and } \\
\text { Commercial Source }\end{array}$ & Salt Treatments & $\begin{array}{l}\text { Growing } \\
\text { Conditions }\end{array}$ & Effects of Grafting & $\begin{array}{l}\text { Key Mechanisms of } \\
\text { Grafted Plant } \\
\text { Tolerance }\end{array}$ & Reference \\
\hline $\begin{array}{c}\text { 'Belladona' } \\
\text { (Hazera seeds) }\end{array}$ & $\begin{array}{c}\text { 'He-man' }(S . \\
\text { lycopersicum } \times \text { S. } \\
\text { habrochaites), } \\
\text { (Syngenta seeds) } \\
\text { 'Resistar' (Hazera } \\
\text { Seeds) }\end{array}$ & $\begin{array}{l}0.3 \text { (control), } 22 \text { and } \\
45 \mathrm{mM} \mathrm{NaCl} \text {, } \\
\text { corresponding to EC } \\
\text { of } 2.5,5.0 \text { and } \\
7.5 \mathrm{dS} \mathrm{m}^{-1}, \\
\text { respectively }\end{array}$ & $\begin{array}{l}\text { Recirculating nutrient } \\
\text { solution in channel, in } \\
\text { greenhouse (long } \\
\text { term, } 6 \text { moths) }\end{array}$ & $\begin{array}{c}\text { High yield, fruit } \\
\text { number and least leaf } \\
\text { chlorosis }\end{array}$ & Low $\mathrm{Na}^{+}$ & Savvas et al. [128] \\
\hline $\begin{array}{c}\text { ‘Big Dena' (Syngenta } \\
\text { seeds) }\end{array}$ & $\begin{array}{c}\text { 'Maxifort' }(S . \\
\text { lycopersicum } \mathrm{L} . \times \text { S. } \\
\text { habrochaites) } \\
\text { (De Ruiter Seed) }\end{array}$ & $\begin{array}{l}\text { Salinity levels: } 0.03, \\
-0.15,-0.30,-0.45 \text { and } \\
-0.60 \mathrm{MPa} \text { osmotic } \\
\text { pressure that were } \\
\text { correspond to EC } 1.2, \\
4.0,8.5,12 \text { and } \\
15.8 \mathrm{dS} \mathrm{m}^{-1} \\
\text { respectively }\end{array}$ & $\begin{array}{l}\text { Sand tank fed by } \\
\text { nutrient solution of } \\
\text { different EC }\end{array}$ & High absolute yield & $\mathrm{Na}+$ exclusion & $\begin{array}{c}\text { Semiz and Suarez } \\
{[73]}\end{array}$ \\
\hline $\begin{array}{c}\text { 'Farida' } \\
\text { (Golden Valley Seed) }\end{array}$ & $\begin{array}{c}\text { ‘Unifort' }(S . \\
\text { lycopersicum } \mathrm{L} . \times S . \\
\text { habrochaites) } \\
\text { (De Ruiter Seed) }\end{array}$ & $\begin{array}{c}\text { Non-saline }(\mathrm{EC}, 1.2 \\
\left.\mathrm{dSm}{ }^{-1}\right) \text { and saline } \\
\text { water }\left(\mathrm{EC}, 4.5 \mathrm{dSm}^{-1}\right) ; \\
\text { these were applied at } \\
100 \%, 75 \%, 50 \% \text { etc. }\end{array}$ & $\begin{array}{l}\text { In soil plots (area, } 8 \\
\mathrm{~m}^{2} \text { ) under } \\
\text { greenhouse }\end{array}$ & $\begin{array}{c}\text { High vegetative } \\
\text { growth, yield and } \\
\text { WUE }\end{array}$ & $\begin{array}{l}\mathrm{Na}+\text { and } \mathrm{Cl}- \\
\text { exclusion }\end{array}$ & Wahb-Allah [129] \\
\hline
\end{tabular}




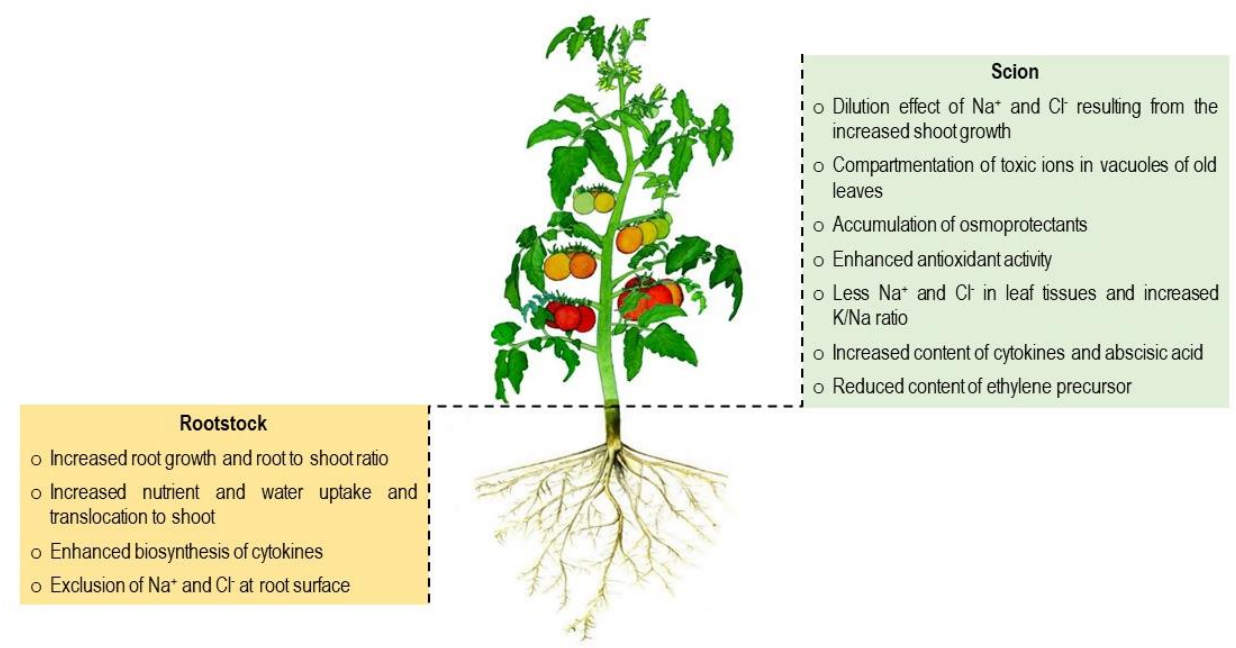

Figure 1. Physiological adaptive traits to mitigate the effect of salt stress in grafted plants.

\section{Potential Use of Wild Tomato Species as Rootstocks for Improving Salt Tolerance in Tomato}

Selection of salt-tolerant rootstocks is an important strategy to enhance salt tolerance. Testing and screening of available commercial and wild relatives under salt stress conditions is a prerequisite for grafting. Natural genetic variation with specific root characters can be utilized effectively through grafting [14]. Various wild tomato/Solanum species including S. cheesmaniae, S. chmielewskii, S. habrochaites, S. pennellii, S. pimpinellifolium and S. peruvianum demonstrate salt tolerance [12,85]. Due to incompatibility in crossing and linkage drag, it is cumbersome to transfer salt tolerant genes from wild to cultivated tomato cultivars [12]. However, these wild species could be exploited as salt-resistant rootstocks for grafting susceptible but high yielding commercial tomato cultivars. Compared to commercially grown tomato (S. lycopersicum) that usually excludes toxic ions [47], several wild relatives possess an ionic inclusion mechanism. These genotypes have the capability to accumulate higher $\mathrm{Na}^{+}$ and $\mathrm{Cl}^{-}$concentrations in the leaves [85]. Breeding new rootstocks with tolerance or resistance to a spectrum of biotic and abiotic stresses is a focus of the private [19] as well as public sectors [11].

Use of interspecific hybrids as rootstocks for salt tolerance is well documented $[6,64,85]$. In this technique, recombinant inbred lines (RILs) created from interspecific crosses are directly used as rootstocks to enhance salinity tolerance. Evaluation of RILs as rootstocks derived from interspecific crosses under salt stress was demonstrated by Albacete et al. [85]. A commercial tomato hybrid cv. 'Boludo' was used to graft onto rootstocks (RILs derived from the cross of S. lycopersicum and S. cheesmaniae) and grown on soil with $75 \mathrm{mM} \mathrm{NaCl}$ salt concentration. These RILs showed good performance under salt stress by affecting growth, and target ionic and hormonal factors in the leaves. They displayed the correlation of rootstock-altered leaf area with $20 \%$ more fruit yield compared to self-grafted plants of the scion hybrid under salt pressure, but not under the control [7,75], indicating that canopy development only limited yield under salt stress [14]. For high salt tolerance, rootstock plants should capable of decreasing the salt load in the foliage cells by excluding the salt ions or accumulating salt in the roots, resulting in a reduction of salt transportation to the shoot system of the plant [21].

While intraspecific grafting is a common practice, efforts also have been made to use interspecific grafting to alleviate wide-spectrum pathogen and environmental pressure without affecting scion fruit yield and quality. Accessions of wild tomato species S. pimpinellifolium were screened for salt tolerance by Rao et al. [12], who suggested the species could be a potential salt tolerance source for tomato breeding and at the same time be used for interspecific grafting to enhance salt tolerance in commercial cultivars. Their results indicated that shoot dry weight and the ratio of $\mathrm{K}^{+}$and $\mathrm{Na}^{+}$are the two most critical factors for survival, while fruit number is critical for yield per plant under saline 
conditions. Two genotypes exhibited high survival rates and produced more fruit under salt stress, and these accessions showed tolerance to $40 \mathrm{dS} \mathrm{m}^{-1}$ EC level.

\section{Conclusions and Challenges Ahead}

Climate change, water scarcity and human activities are increasing soil salinity and depleting arable land. High salinity in soil or water is a serious threat to plant growth and prevents plants from reaching their genetic potential, which reduces yields and threatens food security. Grafting can reduce the negative effects of salinity on tomato scions and thus provides an alternative way to enhance salt tolerance and maintain fruit yield and quality under salt stress. The selection of salt-tolerant rootstocks is an important strategy for enhancing salt tolerance. Testing and screening of available commercial cultivars, landraces and wild relatives, and inbred lines or hybrids involving a resistant parent under salt stress conditions is a prerequisite for successful grafting. This technique can cause both positive and negative effects on yield and fruit characteristics when tomatoes are grown under saline conditions. Weather, salinity level, soil type, cultural practices and consumer preferences also vary in different locations or countries, so the combination of scion and rootstock should be selected carefully at plants morphometric, physio-biochemical and molecular planes to get the maximum benefit from grafting.

Author Contributions: H.S. Wrote the initial draft of the review including yield and quality of grafted tomatoes under salinity; A.K. First draft of physio-biochemical and molecular aspects. P.K. Improved the first draft, contributed to the morphological, physio-biochemical mechanism, and prepared the graph. M.C.K., G.C. and Y.R. critically revised and improved the review paper. All authors have read and agreed to the published version of the manuscript.

Acknowledgments: The authors acknowledge Punjab Agricultural University, Ludhiana and ICAR-Central Arid Zone Research Institute, Jodhpur, India for providing supports.

Conflicts of Interest: The authors declare no conflict of interest.

\section{References}

1. Roychoudhury, A.; Paul, S.; Basu, S. Cross-talk between abscisic acid-dependent and abscisic acid-independent pathways during abiotic stress. Plant Cell Rep. 2013, 32, 985-1006. [CrossRef] [PubMed]

2. Foolad, M.R. Recent advances in genetics of salt tolerance in tomato. Plant Cell Tissue Organ. Cult. 2004, 76, 101-119. [CrossRef]

3. Arzani, A. Improving salinity tolerance in crop plants: A biotechnological view. In Vitro Cell. Dev. Biol. Plant 2008, 44, 373-383. [CrossRef]

4. Zheng, Q.; Liu, J.; Liu, R.; Wu, H.; Jiang, C.; Wang, C.; Guan, Y. Temporal and spatial distributions of sodium and polyamines regulated by brassinosteroids in enhancing tomato salt resistance. Plant Soil 2016, 400, 147-164. [CrossRef]

5. Sholi, N.J. Effect of salt stress on seed germination, plant growth, photosynthesis and ion accumulation of four tomato cultivars. Am. J. Plant Physiol. 2012, 7, 269-275. [CrossRef]

6. Estañ, M.T.; Villalta, I.; Bolarin, M.C.; Carbonell, E.A.; Asins, M.J. Identification of fruit yield loci controlling the salt tolerance conferred by Solanum rootstocks. Theor. Appl. Genet. 2009, 118, 305-312. [CrossRef]

7. Lim, M.Y.; Jeong, B.R.; Jung, M.; Harn, C.H. Transgenic tomato plants expressing strawberry d-galacturonic acid reductase gene display enhanced tolerance to abiotic stresses. Plant Biotechnol. Rep. 2016, 10, 105-116. [CrossRef]

8. Keatinge, J.D.H.; Lin, L.J.; Ebert, A.W.; Chen, W.Y.; Hughes, J.A.; Luther, G.C.; Wang, J.F.; Ravishankar, M. Overcoming biotic and abiotic stresses in the Solanaceae through grafting: Current status and future perspectives. Biol. Agric. Hortic. 2014, 30, 272-287. [CrossRef]

9. Dehyer, R.; Gordon, I. Irrigation water quality. I-salinity and soil structure stability. Nat. Res. Sci. 2005, 55, $55-60$.

10. Al-Harbi, A.; Hejazi, A.; Al-Omran, A. Responses of grafted tomato (Solanum lycopersiocon L.) to abiotic stresses. Saudi, J. Biol. Sci. 2016, 24, 1274-1280. [CrossRef]

11. Colla, G.; Rouphael, Y.; Leonardi, C.; Bie, Z. Role of grafting in vegetable crops grown under saline conditions. Sci. Hortic. 2010, 127, 147-155. [CrossRef] 
12. Rao, E.S.; Kadirvel, P.; Symonds, R.C.; Ebert, A.W. Relationship between survival and yield related traits in Solanum pimpinellifolium under salt stress. Euphytica 2013, 190, 215-228. [CrossRef]

13. Kumar, P.; Rouphael, Y.; Cardarelli, M.; Colla, G. Vegetable Grafting as a Tool to Improve Drought Resistance and Water Use Efficiency. Front. Plant Sci. 2017, 8, 1130. [CrossRef] [PubMed]

14. Albacete, A.; Martínez-Andújar, C.; Martínez-Pérez, A.; Thompson, A.J.; Dodd, I.C.; Pérez-Alfocea, F.R. Unravelling rootstock-scion interactions to improve food security. J. Exp. Bot. 2015, 66, 2211-2226. [CrossRef]

15. Martorana, M.; Giuffrida, F.; Leonardi, C.; Kaya, S. Influence of rootstock on tomato response to salinity. Acta Hortic. 2007, 747, 555-561. [CrossRef]

16. Colla, G.; Rouphael, Y.; Jawad, R.; Kumar, P.; Rea, E.; Cardarelli, M. The effectiveness of grafting to improve $\mathrm{NaCl}$ and $\mathrm{CaCl}_{2}$ tolerance in cucumber. Sci. Hortic. 2013, 164, 380-391. [CrossRef]

17. Tateishi, K. Grafting watermelon onto pumpkin. J. Jpn. Hortic. 1927, 39, 5-8.

18. Besri, M. Current situation of tomato grafting as alternative to methyl bromide for tomato production in Morocco. In Proceedings of the Annual International Research Conference on Methyl Bromide Alternatives and Emission Reductions, San Diego, CA, USA, 28-31 October 2007; pp. 62.1-62.5.

19. King, S.R.; Davis, A.R.; Zhang, X.; Crosby, K. Genetics, breeding and selection of rootstocks for Solanaceae and Cucurbitaceae. Sci. Hortic. 2010, 127, 106-111. [CrossRef]

20. Kubota, C.; McClure, M.A.; Kokalis-Burelle, N.; Bausher, M.G.; Rosskopf, E.N. Vegetable grafting: History, use, and current technology status in North America. Sci. Hortic. 2008, 43, 1644-1669. [CrossRef]

21. Edelstein, M.; Cohen, R.; Baumkoler, F.; Ben-Hur, M. Using grafted vegetables to increase tolerance to salt and toxic elements. Isr. J. Plant Sci. 2016, 1-18. [CrossRef]

22. Cohen, R.; Omari, N.; Porat, A.; Edelstein, M. Management of Macrophomina wilt in melons using grafting or fungicide soil application: Pathological, horticultural and economical aspects. Crop Prot. 2012, 35, 58-63. [CrossRef]

23. Kubota, C. How to Produce Grafted Vegetable Plants; Kubota, C., Miles, C., Zhao, X., Eds.; Grafting manual: Washington, DC, USA, 2016; pp. 1-5.

24. Besri, M. Economic aspects of grafting tomato in some Mediterranean countries. In Proceedings of the Annual International Research Conference on Methyl Bromide Alternatives and Emissions Reductions proceedings, San Diego, CA, USA, 29 October-1 November 2007; p. 62-1-5.

25. Singh, H.; Kumar, P.; Chaudhari, S.; Edelstein, M. Tomato grafting: A Global perspective. HortScience 2017, 52, 1328-1336. [CrossRef]

26. Sardoo, M.; Fatemeh, S. Evaluation of salt tolerance of tomato (Lycopersicon esculentum). Agric. Adv. 2016, 5, 221-226.

27. Abbasi, H.; Jamil, M.; Haq, A.; Ali, S.; Ahmad, R.; Malik, Z. Salt stress manifestation on plants, mechanism of salt tolerance and potassium role in alleviating it: A review. Zemdirbyste Agric. 2016, 103, 229-238. [CrossRef]

28. Parida, AK.; Das, A.B. Salt tolerance and salinity effects on plants. Ecotox. Environ. Saf. 2005, 60, 324-349. [CrossRef]

29. Rivero, R.M.; Ruiz, J.M.; Romero, L. Role of grafting in horticultural plants under stress conditions. J. Food Agric. Environ. 2003, 1, 70-74.

30. Colla, G.; Kumar, P.; Cardarelli, M.; Rouphael, Y. Grafting an effective tool for abiotic stress alleviation in vegetables. In Horticulture for Food and Environment Security; Chadha, K.L., Singh, A.K., Singh, S.K., Dhillon, W.S., Eds.; Westville Publishing House: New Delhi, India, 2012; pp. 15-28.

31. Rajaei, S.M.; Niknam, V.; Seyedi, S.M.; Ebrahimzadeh, H.; Razavi, K. Contractile roots are the most sensitive organ in Crocus sativus to salt stress. Biol. Plant. 2009, 53, 523. [CrossRef]

32. Chaves, M.M.; Costa, J.M.; Saibo, N.J.M. Recent advances in photosynthesis under drought and salinity. Adv. Bot. Res. 2011, 57, 49-104.

33. Mahajan, S.; Tuteja, N. Cold, salinity and drought stresses: An overview. Arch. Biochem. Biophys. 2005, 444, 139-158. [CrossRef]

34. Cuartero, J.; Bolarin, M.C.; Asins, M.J.; Moreno, V. Increasing salt tolerance in the tomato. J. Exp. Biol. 2006, 57, 1045-1058. [CrossRef]

35. Hajer, A.S.; Malibari, A.A.; Al-Zahrani, H.S.; Almaghrabi, O.A. Responses of three tomato cultivars to sea water salinity 1. Effect of salinity on the seedling growth. Afr. J. Biotechnol. 2006, 5, 855-861. 
36. Najla, S.; Vercambre, G.; Page's, L.; Grasselly, D.; Gautier, H.; Ge'nard, M. Tomato plant architecture as affected by salinity: Descriptive analysis and integration in a 3-D simulation model. Botany 2009, 87, 893-904. [CrossRef]

37. Cuartero, J.; Fernández-Muñoz, R. Tomato and salinity. Sci. Hortic. 1999, 78, 83-125. [CrossRef]

38. Khavari-Nejad, R.A.; Mostofi, Y. Effects of $\mathrm{NaCl}$ on photosynthetic pigments, saccharides, and chloroplast ultrastructure in leaves of tomato cultivars. Photosynthetica 1998, 35, 151-154. [CrossRef]

39. Al-Karaki, G.N. Growth, water use efficiency, and sodium and potassium acquisition by tomato cultivars grown under salt stress. J. Plant. Nutr. 2000, 23, 1-8. [CrossRef]

40. Turhan, A.; Seniz, V.; Kusçu, H. Genotypic variation in the response of tomato to salinity. Afr. J. Biotechnol. 2009, 8, 1062-1068.

41. Gao, Z.; Sagi, M.; Lips, S.H. Carbohydrate metabolism in leaves and assimilate partitioning in fruits of tomato (Lycopersicon esculentum L.) as affected by salinity. Plant Sci. 1998, 135, 149-159. [CrossRef]

42. De Pascale, S.; Maggio, A.; Fogliano, V.; Ambrosino, P.; Ritieni, A. Irrigation with saline water improves carotenoids content and antioxidant activity of tomato. J. Hortic. Sci. Biotechnol. 2001, 76, 447-453. [CrossRef]

43. Di Gioia, F.; Signore, A.; Serio, F.; Santamaria, P. Grafting improves tomato salinity tolerance through sodium partitioning within the shoot. HortScience 2013, 48, 855-862. [CrossRef]

44. Balliu, A.; Vuksani, G.; Nasto, T.; Haxhinasto, L.; Kaçiu, S. Grafting effects on tomato growth rate, yield and fruit quality under saline irrigation water. Acta Hortic. 2007, 801, 1161-1166. [CrossRef]

45. Santa-Cruz, A.; Martínez-Rodríguez, M.M.; Cuartero, J.; Bolarin, M.C. Response of plant yield and ion contents to salinity in grafted tomato plants. Acta Hortic. 2001, 559, 413-417. [CrossRef]

46. Santa-Cruz, A.; Martínez-Rodríguez, M.M.; Pérez-Alfocea, F.; Romero-Aranda, R.; Bolarin, M.C. The rootstock effect on the tomato salinity response depends on the shoot genotype. Plant Sci. 2002, 162, 825-831. [CrossRef]

47. Voutsela, S.; Yarsi, G.; Petropoulos, S.A.; Khan, E.A. The effect of grafting of five different rootstocks on plant growth and yield of tomato plants cultivated outdoors and indoors under salinity stress. Afr. J. Agric. Res. 2012, 7, 5553-5557. [CrossRef]

48. Iseri, O.D.; Körpe, D.A.; Sahin, F.I.; Haberal, M. High salt induced oxidative damage and antioxidant response in tomato grafted on tobacco. Chil. J. Agric. Res. 2015, 75, 192-201.

49. Turhan, A.; Ozmen, N.; Serbeci, M.S.; Seniz, V. Effects of grafting on different rootstocks on tomato fruit yield and quality. Sci. Hortic. 2011, 38, 142-149. [CrossRef]

50. Flores, F.B.; Sanchez-Bel, P.; Estañ, M.T.; Martinez-Rodriguez, M.M.; Moyano, E.; Morales, B.; Campos, J.F.; Garcia-Abellán, J.O.; Egea, M.I.; Fernández-García, N.; et al. The effectiveness of grafting to improve tomato fruit quality. Sci. Hortic. 2010, 125, 211-217. [CrossRef]

51. He, Y.; Zhu, Z.; Yang, J. Grafting increases the salt tolerance of tomato by improvement of photosynthesis and enhancement of antioxidant enzymes activity. Environ. Exp. Bot. 2009, 66, 270-278. [CrossRef]

52. Oztekin, G.B.; Tuzel, Y. Salinity response of some tomato rootstocks at seedling stage. Afr. J. Agric. Res. 2011, 6, 4726-4735.

53. Gregory, P.J.; Atkinson, C.J.; Bengough, A.G.; Else, M.A.; Fernández-Fernández, F.; Harrison, R.J.; Schmidt, S. Contributions of roots and rootstocks to sustainable, intensified crop production. J. Exp. Bot. 2013, 64, 1209-1222. [CrossRef]

54. Martínez-Rodríguez, M.M.; Estañ, M.T.; Moyano, E.; Garcia-Abellan, J.O.; Flores, F.B.; Campos, J.F.; Al-Azzawi, M.J.; Flower, T.J.; Bolarin, M.C. The effectiveness of grafting to improve salt tolerance in tomato when an 'excluder' genotype is used as scion. Environ. Exp. Bot. 2008, 63, 392-401. [CrossRef]

55. Zhen, A.; Bie, Z.; Huang, Y.; Liu, Z.; Li, Q. Effects of scion and rootstock genotypes on the anti-oxidant defense systems of grafted cucumber seedlings under $\mathrm{NaCl}$ stress. Soil Sci. Plant Nutr. 2010, 56, $263-271$. [CrossRef]

56. Turquois, N.; Malone, M. Non-destructive assessment of developing hydraulic connections in the graft union of tomato. J. Exp. Bot. 1996, 298, 701-707. [CrossRef]

57. Huang, Y.; Zhao, L.Q.; Kong, Q.S.; Cheng, F.; Niu, M.L.; Xie, J.J.; Nawaz, M.A.; Bie, Z.L. Comprehensive mineral nutrition analysis of watermelon grafted onto two different rootstocks. Hort. Plant J. 2016, 2, 105-113. [CrossRef]

58. Ruiz, D.; Martínez, V.; Cerda, A. Citrus response to salinity, growth and nutrient uptake. Tree Physiol. 1997, 17, 141-150. [CrossRef] [PubMed] 
59. Fernández-García, N.; Martinez, V.; Cerdá, A.; Carvajal, M. Water and nutrient uptake of grafted tomato plants grown under saline conditions. J. Plant Physiol. 2002, 159, 899-905. [CrossRef]

60. Shalhevet, J.; Maas, E.V.; Hoffman, G.J.; Ogata, G. Salinity and the hydraulic conductance of roots. Physiol. Plant. 1976, 38, 224-232. [CrossRef]

61. Munns, R.; Passioura, J.B. Hydraulic resistance of plants. III. Effects of $\mathrm{NaCl}$ in barley and lupin. Aust. J. Plant Physiol. 1984, 11, 351-359. [CrossRef]

62. Evlagon, D.; Ravina, Y.; Neumann, P.M. Interactive effects of salinity and calcium on hydraulic conductivity, osmotic adjustment and growth in primary roots of maize seedlings. Isr. J. Bot. 1990, 39, 239-247.

63. Carvajal, M.; Martínez, V.; Alcaraz, C.F. Physiological function of water-channels, as affected by salinity in roots of paprika pepper. Physiol. Plant. 1999, 105, 95-101. [CrossRef]

64. Estañ, M.T.; Martinez-Rodriguez, M.M.; Perez-Alfocea, F.; Flowers, T.J.; Bolarin, M.C. Grafting raises the salt tolerance of tomato through limiting the transport of sodium and chloride to the shoot. J. Exp. Bot. 2005, 56, 703-712. [CrossRef]

65. Lee, J.M. Cultivation of grafted vegetables I. Current status, grafting methods, and benefits. HortScience 1994, 29, 235-239. [CrossRef]

66. Zijlstra, S.; Groot, S.P.C.; Jansen, J. Genotypic variation of rootstocks for growth and production in cucumber; possibilities for improving the root system by plant breeding. Sci. Hortic. 1994, 56, 185-196. [CrossRef]

67. Leoni, S.; Grudina, R.; Cadinu, M.; Madeddu, B.; Carletti, M.G. The influence of four rootstocks on some melon hybrids and a cultivar in greenhouse. II Inter. Sym. Protec. Culti. Veg. Mild Winter Clim. 1990, 287, 127-134. [CrossRef]

68. Moya, J.L.; Primo-Millo, E.; Talón, M. Morphological factors determining salt tolerance in citrus seedlings: The shoot to root ratio modulates passive root uptake of chloride ions and their accumulation in leaves. Plant Cell. Environ. 1999, 22, 1425-1433. [CrossRef]

69. Zhu, J.; Bie, Z.; Huang, Y.; Han, X. Effect of grafting on the growth and ion concentrations of cucumber seedlings under $\mathrm{NaCl}$ stress. Soil Sci. Plant Nutr. 2008, 54, 895-902. [CrossRef]

70. Pérez-Alfocea, F.; Albacete, A.; Ghanem, M.E.; Dodd, I.C. Hormonal regulation of source-sink relations to maintain crop productivity under salinity: A case study of root-to-shoot signalling in tomato. Funct. Plant Biol. 2010, 37, 592-603. [CrossRef]

71. Martinez-Rodriguez, M.M.; Santa-Cruz, A.; Estan, M.T.; Caro, M.; Bolarin, M.C. Influence of rootstock in the tomato response to salinity. Acta Hortic. 2002, 573, 455-460. [CrossRef]

72. Fernández-García, N.; Martínez, V.; Carvajal, M. Effect of salinity on growth, mineral composition, and water relations of grafted tomato plants. J. Plant Nutr. Soil Sci. 2004, 167, 616-622. [CrossRef]

73. Semiz, G.D.; Suarez, D.L. Tomato salt tolerance: Impact of grafting and water composition on yield and ion relations. Turk. J. Agric. For. 2015, 39, 876-886. [CrossRef]

74. Munns, R. Genes and salt tolerance: Bringing them together. New Phytol. 2005, 167, 645-663. [CrossRef]

75. Pérez-Alfocea, F.; Estañ, M.T.; Caro, M.; Bolarín, M.C. Response of tomato cultivars to salinity. Plant Soil. 1993, 150, 203-211. [CrossRef]

76. Pérez-Alfocea, F.; Balibrea, M.E.; Santa Cruz, A.; Estañ, M.T. Agronomical and physiological characterization of salinity tolerance in a commercial tomato hybrid. Plant Soil. 1996, 180, 251-257. [CrossRef]

77. Tal, M. Salt tolerance in the wild relatives of the cultivated tomato: Responses of Lycopersicon esculentum, L. peruvianum, and L. esculentum minor to sodium chloride solution. Aust. J. Agric. Res. 1971, 22, 631-638. [CrossRef]

78. Rush, D.W.; Epstein, E. Comparative studies on the sodium, potassium, and chloride relations of a wild halophytic and a domestic salt-sensitive tomato species. Plant Physiol. 1981, 68, 1308-1313. [CrossRef]

79. Bolarin, M.C.; Fernandez, F.G.; Cruz, V.; Cuartero, J. Salinity tolerance in four wild tomato species using vegetative yield-salinity response curves. J. Am. Soc. Hort. Sci. 1991, 116, 286-290. [CrossRef]

80. Cuartero, J.; Yeo, A.R.; Flowers, T.J. Selection of donors for salt-tolerance in tomato using physiological traits. New Phytol. 1992, 121, 63-69. [CrossRef]

81. Shannon, M.C. Adaptation of plants to salinity. In Advances in Agronomy; Academic Press: Cambridge, MA, USA, 1997; Volume 60, pp. 75-120.

82. Sacher, R.F.; Staples, R.C.; Robinson, R.W. Saline tolerance in hybrids of Lycopersicon esculentum X Solanum penellii and selected breeding lines. Environ. Sci. Res. 1982, 325-336. 
83. Huang, Y.; Zhu, J.; Zhen, A.; Chen, L.; Bie, Z.L. Organic and inorganic solutes accumulation in the leaves and roots of grafted and ungrafted cucumber plants in response to $\mathrm{NaCl}$ stress. J. Food Agric. Environ. 2009, 7, 703-708.

84. Albacete, A.; Martínez-Andújar, C.R.; Ghanem, M.E.; Acosta, M.; Sánchez-bravo, J.O.; Asins, M.J.; Cuartero, J.; Lutts, S.; Dodd, I.C.; Pérez-Alfocea, F.R. Rootstock-mediated changes in xylem ionic and hormonal status are correlated with delayed leaf senescence, and increased leaf area and crop productivity in salinized tomato. Plant Cell Environ. 2009, 32, 928-938. [CrossRef]

85. Xu, H.L.; Gauthier, L.; Gosselin, A. Photosynthetic responses of greenhouse tomato plants to high solution electrical conductivity and low soil water content. J. Hortic. Sci. 1994, 69, 821-832. [CrossRef]

86. Flexas, J.; Bota, J.; Loreto, F.; Cornic, G.; Sharkey, T.D. Diffusive and metabolic limitations to photosynthesis under drought and salinity in $C_{3}$ plants. Plant Biol. 2004, 6, 269-279. [CrossRef] [PubMed]

87. Zhen, A.; Bie, Z.; Huang, Y. Effects of salt-tolerant rootstock grafting on ultrastructure, photosynthetic capacity, and $\mathrm{H}_{2} \mathrm{O}_{2}$-scavenging system in chloroplasts of cucumber seedlings under $\mathrm{NaCl}$ stress. Acta Physiol. Plant. 2011, 33, 2311. [CrossRef]

88. Liu, Z.; Bie, Z.; Huang, Y. Rootstocks improve cucumber photosynthesis through nitrogen metabolism regulation under salt stress. Acta Physiol. Plant. 2013, 35, 2259-2267. [CrossRef]

89. Marsic, N.K.; Vodnik, D.; Mikulic-Petkovsek, M.; Veberic, R.; Sircelj, H. Photosynthetic Traits of Plants and the Biochemical Profile of Tomato Fruits Are Influenced by Grafting, Salinity Stress, and Growing Season. J. Agric. Food Chem. 2018, 66, 5439-5450. [CrossRef]

90. Feng, X.; Guo, K.; Yang, C.; Li, J.; Chen, H.; Liu, X. Growth and fruit production of tomato grafted onto wolfberry (Lycium chinense) rootstock in saline soil. Sci. Hortic. 2019, 255, 298-305.

91. Bartoli, C.G.; Buet, A.; Grozeff, G.G. Ascorbate-glutathione cycle and abiotic stress tolerance in plants. In Ascorbic Acid in Plant. Growth, Development and Stress Tolerance; Springer: Cham, Germany, 2017; pp. 177-200.

92. Gao, J.J.; Zhang, L.; Qin, A.G.; Yu, X.C. Relative expression of SOD and CAT mRNA and activities of SOD and CAT in grafted cucumber leaves under $\mathrm{NaCl}$ stress. Ying yong sheng tai xue bao. J. Appl. Ecol. 2008, 19, 1754-1758.

93. Wei, G.P.; Yang, L.F.; Zhu, Y.L.; Chen, G. Changes in oxidative damage, antioxidant enzyme activities and polyamine contents in leaves of grafted and non-grafted eggplant seedlings under stress by excess of calcium nitrate. Sci. Hortic. 2009, 120, 443-451. [CrossRef]

94. Ruiz, J.M.; Ríos, J.J.; Rosales, M.A.; Rivero, R.M.; Romero, L. Grafting between tobacco plants to enhance salinity tolerance. J. Plant Physiol. 2006, 163, 1229-1237. [CrossRef]

95. Yasinok, A.E.; Feride, S.I.; Eyidogan, F.; Kuru, M.; Haberal, M. Grafting tomato plant on tobacco plant and its effect on tomato plant yield and nicotine content. J. Sci. Food Agric. 2009, 89, 1122-1128. [CrossRef]

96. Singh, J.; Sastry, E.V.D.; Singh, V. Effect of salinity on tomato (Lycopersicon esculentum Mill.) during seed germination stage. J. Plant Physiol. Molecular Biol. 2012, 18, 45-50. [CrossRef] [PubMed]

97. Ja'afar, U.; Aliero, A.A.; Shehu, K.; Abubakar, L. Genetic diversity in tomato genotypes (Solanum lycopersicum) based on salinity responsive candidate gene using simple sequence repeats. International Lett. Nat. Sci. 2018, 72, 37-46. [CrossRef]

98. Yveline, P.; Awlia, M.; Julkowska, M.; Passone, L.; Zemmouri, K.; Negrão, S.; Schmöckel, S.M.; Tester, M. Diverse traits contribute to salinity tolerance of wild tomato seedlings from the Galapagos Islands. Plant. Physiol. 2020, 182, 534-546.

99. Asins, M.J.; Raga, V.; Roca, D.; Belver, A.; Carbonell, E.A. Genetic dissection of tomato rootstock effects on scion traits under moderate salinity. Theor. Appl Genet. 2015, 128, 667-679. [CrossRef]

100. Nedjimi, B. Calcium application enhances plant salt tolerance: A review. Essent. Plant Nutr. Springer 2017, 367-377.

101. Zhao, N.; Wang, S.; Ma, X. Extracellular ATP mediates cellular $\mathrm{K}+/ \mathrm{Na}+$ homeostasis in two contrasting poplar species under $\mathrm{NaCl}$ stress. Trees. 2016, 30, 825-837. [CrossRef]

102. Mahajan, S.; Pandey, G.K.; Tuteja, N. Calcium-and salt-stress signaling in plants: Shedding light on SOS pathway. Arch. Biochem. Bioph. 2008, 471, 146-158. [CrossRef]

103. Shaterian, J.; Georges, F.; Hussain, A. Root to shoot communication and abscisic acid in calreticulin (CR) gene expression and salt-stress tolerance in grafted diploid potato clones. Environ. Exp. Bot. 2005, 53, 323-332. [CrossRef] 
104. Sharma, A.; Zheng, B. Molecular responses during plant grafting and its regulation by auxins, cytokinins, and gibberellins. Biomolecules 2019, 9, 397. [CrossRef]

105. Nanda, A.K.; Melnyk, C.W. The role of plant hormones during grafting. J. Plant Res. 2018, 131, 49-58. [CrossRef]

106. Ruzicka, K.; Ursache, R.; Hejatko, J.; Helariutta, Y. Xylem development-from the cradle to the grave. New Phytol. 2015, 207, 519-535. [CrossRef] [PubMed]

107. Kumar, R.M.S.; Ji, G.; Guo, H.; Zhao, L.; Zheng, B. Over-expression of a grafting-responsive gene from hickory increases abiotic stress tolerance in Arabidopsis. Plant Cell Rep. 2018, 37, 541-552. [CrossRef] [PubMed]

108. Sauer, M.; Balla, J.; Luschnig, C.; Wisniewska, J.; Reinohl, V.; Friml, J.; Benkova, E. Canalization of auxin flow by Aux/IAA-ARF-dependent feedback regulation of PIN polarity. Genes Dev. 2006, 20, 2902-2911. [CrossRef]

109. Yuan, H.; Zhao, L.; Qiu, L.; Xu, D.; Tong, Y.; Guo, W.; Yang, X.; Shen, C.; Yan, D.; Zheng, B. Transcriptome and hormonal analysis of grafting process by investigating the homeostasis of a series of metabolic pathways in Torreya grandis cv. Merrillii. Ind. Crops Prod. 2017, 108, 814-823. [CrossRef]

110. Aloni, R. The role of cytokinin in organised differentiation of vascular tissues. Funct. Plant Biol. 1993, 20, 601-608. [CrossRef]

111. Shehata, S.; El-Shraiy, A.M. Regulating cucumber grafting by interactions of cytokinins in xylem exudates of rootstock and basipetol polar auxin transport of scion at graft union. Aus. J. Basic Appl. Sci. 2010, 4, 6179-6184.

112. Aloni, B.; Cohen, R.; Karni, L.; Aktas, H.; Edelstein, M. Hormonal signaling in rootstock-scion interactions. Sci. Hortic. 2010, 127, 119-126. [CrossRef]

113. Ghanem, M.E.I.; Hichri, A.C.; Smigocki, A.; Albacete, M.L.; Fauconnier, E.; Diatloff, C.; Martı'nez-Andu'jar, M.; Acosta, J.; Sanchez-Bravo, S.; Lutts, I.C.; et al. Root-targeted biotechnology to mediate hormonal signaling and improve crop stress tolerance. Plant Cell Rpt. 2011, 30, 807-823. [CrossRef]

114. Aloni, R.; Aloni, E.; Langhans, M.; Ullrich, C.I. Role of cytokinin and auxin in shaping root architecture: Regulating vascular differentiation, lateral root initiation, root apical dominance and root gravitropism. Ann. Bot. 2006, 97, 883-893. [CrossRef]

115. Ghanem, M.E.; Albacete, A.; Smigocki, A.C.; Frébort, I.; Pospíšilová, H.; Martínez-Andújar, C.; Acosta, M.; Sánchez-Bravo, J.; Lutts, S.; Dodd, I.C.; et al. Root-synthesized cytokinins improve shoot growth and fruit yield in salinized tomato (Solanum lycopersicum L.) plants. J. Exp. Bot. 2011, 62, 125-140. [CrossRef]

116. Asahina, M.; Gocho, Y.; Kamada, H.; Satoh, S. Involvement of inorganic elements in tissue reunion in the hypocotyl cortex of Cucumis sativus. J. Plant Res. 2006, 119, 337-342. [CrossRef] [PubMed]

117. Asahina, M.; Yamauchi, Y.; Hanada, A.; Kamiya, Y.; Kamada, H.; Satoh, S.; Yamaguchi, S. Effects of the removal of cotyledons on endogenous gibberellin levels in hypocotyls of young cucumber and tomato seedlings. Plant Biotechnol. 2007, 24,99-106. [CrossRef]

118. Mo, Z.; Feng, G.; Su, W.; Liu, Z.; Peng, F. Transcriptomic Analysis Provides Insights into Grafting Union Development in Pecan (Carya illinoinensis). Genes 2018, 9, 71. [CrossRef] [PubMed]

119. Bjorklund, S.; Antti, H.; Uddestrand, I.; Moritz, T.; Sundberg, B. Cross-talk between gibberellin and auxin in development of Populus wood: Gibberellin stimulates polar auxin transport and has a common transcriptome with auxin. Plant J. 2007, 52, 499-511. [CrossRef] [PubMed]

120. Dayan, J.; Voronin, N.; Gong, F.; Sun, T.P.; Hedden, P.; Fromm, H.; Aloni, R. Leaf-induced gibberellin signaling is essential for internode elongation, cambial activity, and fiber differentiation in tobacco stems. Plant Cell. 2012, 24, 66-79. [CrossRef]

121. Liu, N.; Yang, J.; Fu, X.; Zhang, L.; Tang, K.; Guy, K.M.; Hu, Z.; Guo, S.; Xu, Y.; Zhang, M. Genome-wide identification and comparative analysis of grafting-responsive mRNA in watermelon grafted onto bottle gourd and squash rootstocks by high-throughput sequencing. Mol. Genet. Genom. 2016, 291, 621-633. [CrossRef]

122. Peña-Cortés, H.; Sánchez-Serrano, J.J.; Mertens, R. Abscisic acid is involved in the wound-induced expression of the proteinase inhibitor II gene in potato and tomato. Proc. Natl. Acad. Sci. USA 1989, 86, 9851-9855. [CrossRef]

123. Peña-Cortés, H.; Fisahn, J.; Willmitzer, L. Signals involved in wound-induced proteinase inhibitor II gene expression in tomato and potato plants. Proc. Natl. Acad. Sci. USA 1995, 92, 4106-4113. [CrossRef] 
124. Chen, G.; Fu, X.; Lips, S.H.; Sagi, M. Control of plant growth resides in the shoot, and not in the root, in reciprocal grafts of flacca and wild-type tomato (Lysopersicon esculentum), in the presence and absence of salinity stress. Plant Soil 2003, 256, 205-215. [CrossRef]

125. Yin, H.; Yan, B.; Sun, J.; Jia, P.; Zhang, Z.; Yan, X.; Chai, J.; Ren, Z.; Zheng, G.; Liu, H. Graft-union development: A delicate process that involves cell-cell communication between scion and stock for local auxin accumulation. J. Exp. Bot. 2012, 63, 4219-4232. [CrossRef]

126. Matsuoka, K.; Sugawara, E.; Aoki, R.; Takuma, K.; Terao-Morita, M.; Satoh, S.; Asahina, M. Differential Cellular Control by Cotyledon-Derived Phytohormones Involved in Graft Reunion of Arabidopsis Hypocotyls. Plant Cell Physiol. 2016, 57, 2620-2631. [CrossRef] [PubMed]

127. Tao, J.J.; Chen, H.W.; Ma, B.; Zhang, W.K.; Chen, S.Y.; Zhang, J.S. The role of ethylene in plants under salinity stress. Front. Plant Sci. 2015, 6, 1059. [CrossRef] [PubMed]

128. Savvas, D.; Savva, A.; Ntatsi, G.; Ropokis, A.; Karapanos, I.; Krumbein, A.; Olympios, C. Effects of three commercial rootstocks on mineral nutrition, fruit yield, and quality of salinized tomato. J. Plant Nutr. Soil Sci. 2011, 174, 154-162. [CrossRef]

129. Wahb-Allah, M.A. Effectiveness of grafting for the improvement of salinity and drought tolerance in tomato (Solanum lycopersicum L.). Asian J. Crop. Sci. 2014, 6, 112-122.

(C) 2020 by the authors. Licensee MDPI, Basel, Switzerland. This article is an open access article distributed under the terms and conditions of the Creative Commons Attribution (CC BY) license (http://creativecommons.org/licenses/by/4.0/). 